Regional Geology Reviews

Maarten J. de Wit · François Guillocheau Michiel C. J. de Wit Editors

Geology and

Resource

Potential of the

Congo Basin

Springer 


\title{
Petroleum Potential of the Congo Basin
}

\author{
Damien Delvaux and Max Fernandez-Alonso
}

\subsection{Introduction}

The Congo Basin (CB) is a broad and long-lived intracratonic depression in the centre of the African Plate covering most of the Democratic Republic of Congo (DRC, formerly Zaire), the People's Republic of Congo and the Central African Republic (CAR), coinciding with a region of pronounced long-wavelength gravity anomaly (Crosby et al. 2010; see also Raveloson et al., Chap. 1, this Book). The $\mathrm{CB}$ has a long ( 600 Ma) and complex history of sediment accumulation, tectonic inversion and erosion since the end-Neoproterozoic (Veatch 1935; Cahen 1954; Cahen and Lepersonne 1954; Lepersonne 1974, 1977; Daly et al. 1992; Giresse 2005; Kadima et al. 2011a; see also Kadima et al., Chap. 6, this Book), and it was affected by the break-up of Gondwana during the Mesozoic (Torsvik and Cocks 2011; see also Linol, Chap. 11, this Book). Today, the CB is still tectonically active along the East African Rift margin (Delvaux and Barth 2010).

The CB contains up to $\sim 9 \mathrm{~km}$ of Neoproterozoic, Paleozoic and Meso-Cenozoic sedimentary sequences (Kadima et al. 2011a; and Delpomdor et al., Chaps. 3, 4; Linol et al., Chaps. 7-9; Kadima et al., Chap. 6, this Book). The basin is believed to have initiated as a Neoproterozoic rift and a large part of its subsequent subsidence history has been modelled by post-rift thermal relaxation (Kadima et al. 2011b; Buiter et al. 2012; Lucazeau et al., Chap. 12, this Book; but see Linol et al., Chap. 11, this Book, for alternative models). Global climate change, Gondwana motions and break-up, and intraplate stresses are the main factors that controlled the tectonostratigraphic evolution of the CB. Several tectonic inversions occurred during its Phanerozoic development as a response to far-field compressional stresses generated at plate boundaries

D. Delvaux $(\triangle) \bullet$ M. Fernandez-Alonso

Geodynamics and Mineral Resources, Royal Museum for Central

Africa, Tervuren, Belgium

e-mail: damien.delvaux@africamuseum.be; max.

fernandez@africamuseum.be (e.g. Daly et al. 1992). This caused depositional hiatus, uplift and erosion periods, faulting and folding, leading to the development of stratigraphic and tectonic unconformities (e.g. Kadima et al., Chap. 6, and Linol et al., Chap. 11, this Book).

Although the petroleum potential of this ca. 1.2 million $\mathrm{km}^{2}$ intra-continental basin has been of interest for decades (Misser 2013), the CB is still one of the largest, least wellunderstood basin in the world due to relatively limited observational data. Only two stratigraphic wells and two deep petroleum wells have been drilled since exploration began in the 1950s. Many important aspects of its geological knowledge and petroleum systems remain poorly constrained, such as: its regional tectonic framework and internal structure, the stratigraphy of the basin fill, potential source rock levels, reservoirs and seal facies, its burial and thermal history, and so forth. Despite this, the CB is considered by some as a new future petroleum province (e.g. Mello 2008; Pilipili Mawezi (2010). Here, we re-evaluate the petroleum potential of the $\mathrm{CB}$ in light of geochemical data from both academic and industrial sources.

\subsection{History of Petroleum Investigation}

As early as the beginning of the twentieth century, Cornet (1911), then Passau (1923) recognized that the CB (Fig. 18.1) contains organic-rich rocks with potential for oil and gas. The first exploration project was performed between 1952 and 1956 (Mission REMINA-Syndicat pour l'étude géologique et minière de la cuvette congolaise), with geological field investigations, combined gravity and magnetic measurements, $600 \mathrm{~km}$ of refraction seismic profiles, $131 \mathrm{~km}$ of seismic reflection profiles, and two $\sim 2,000 \mathrm{~m}$ deep fully cored stratigraphic wells (Samba and Dekese). The results have been largely published in the Annales of the Royal Museum for Central Africa (RMCA), in Tervuren, Belgium, where outcrop samples and cores are also archived. 


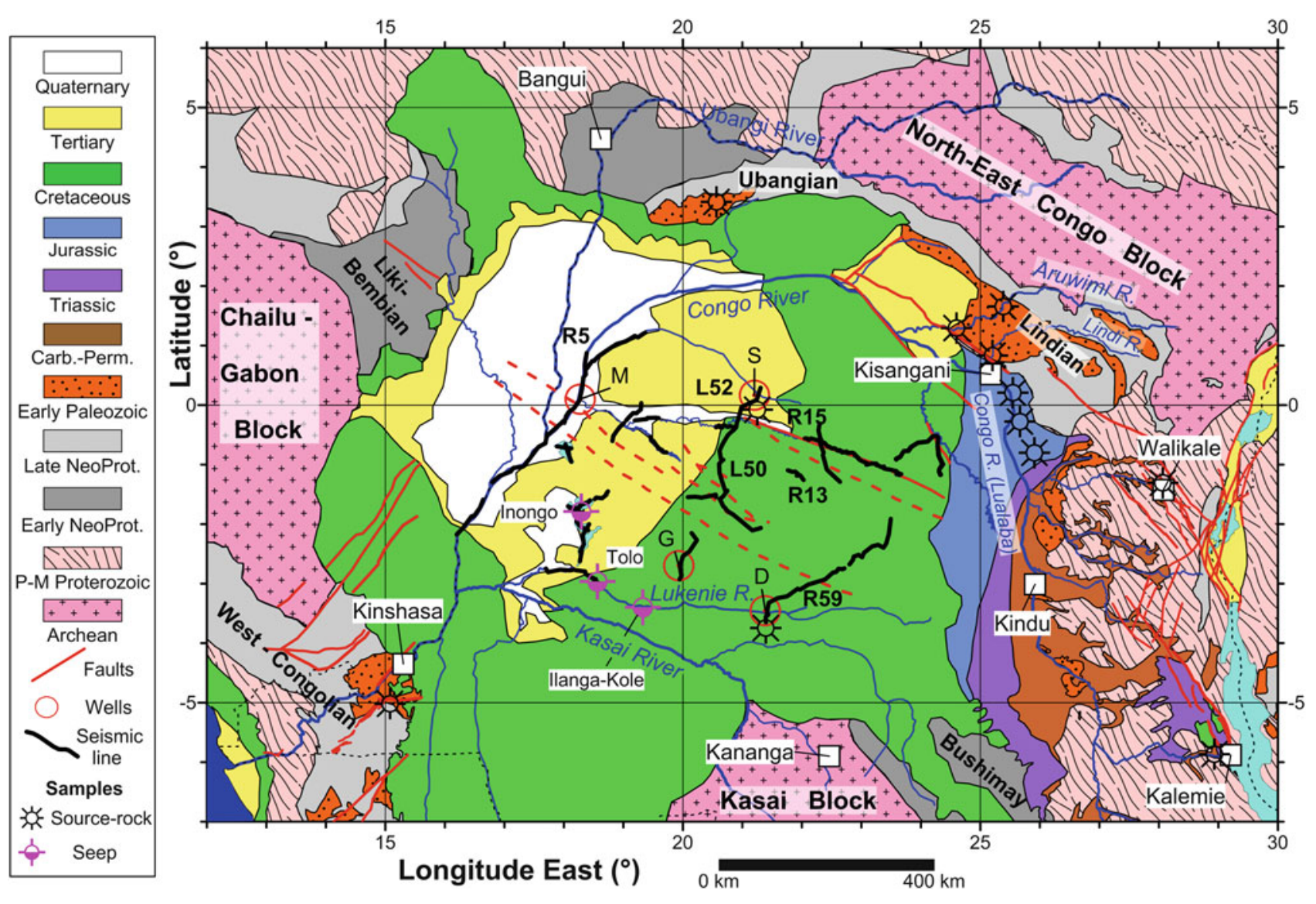

Fig. 18.1 Simplified geological map of the Congo Basin with location of the samples referred to in the text (geology modified from Lepersonne 1974)

A second major exploration phase was conducted between 1974 and 1976 by the Esso-Texaco consortium, which acquired 2,900 km of reflection seismic profiles and drilled two ca. 4,000 m-deep exploration wells (Mbandaka-1 and Gilson-1). The results of this exploration are synthesized in the Hydrocarbon Potential of the Cuvette Centrale Report (ECL 1988) and further discussed in Lawrence and Makazu (1988) and Daly et al. (1992). Unfortunately, most of the detailed results are unpublished. The two exploration wells proved negative with respect to oil potential, but provided valuable stratigraphic and rock information as well as welllogs. Both wells have a dominant siliciclastic lithology, including good potential reservoir rocks (e.g. abundant aeolian sandstone units) but encountered no hydrocarbon shows. A bitumen residue was found in black-grey shales and siltstones of the Mbandaka-1 well between depths of 2,810-3,425 $\mathrm{m}$. This well was drilled almost entirely in red sandstones and conglomerates (ESSO Zaire 1981a). It encountered Neoproterozoic carbonates at $4,133 \mathrm{~m}$ deep and bottomed in evaporate and probable halite salt at $4,350 \mathrm{~m}$. Due to its dominantly clastic nature and near absence of microfossil remains, age constraints are scarce (for detailed biostratigraphy, see Colin 1981; Linol 2013, who describes abundant ostracods), and stratigraphic correlations with the other wells and outcrops are difficult. Only a few layers of black shales were encountered, but with negligible source-rock potential. Similarly, the Gilson-1 well encountered no source rock, potential seals or hydrocarbon shows (ESSO Zaire 1981b). It has also a dominant clastic lithology of continental origin and Neoproterozoic carbonates at the base, suggesting restricted marine to lagoon conditions (see Delpomdor et al., Chaps. 3 and 4, this Book for detailed descriptions of the Neoproterozoic carbonates).

The last oil exploration-phase was completed in 1984 by the Japan National Oil Corporation (JNOC), including aeromagnetic and gravity surveys with source rock investigations (JNOC 1984). It concentrated along the eastern rim of the $\mathrm{CB}$, where the Middle Cretaceous Loia and the Upper Jurassic Stanleyville Groups are outcropping. Several source rock horizons have been identified in outcrops and in boreholes. Where sampled, the most promising ones are not within the oil maturation window, but they may have generated hydrocarbons in deeper parts of the basin (Sachse et al. 2012). 
Since the JNOC campaign, several reviews of the existing data have been prepared by Oil Search/Pioneer (2007) and HRT Petroleum (Mello 2008), in order to evaluate the hydrocarbon potential of the $\mathrm{CB}$, with the aim of attracting potential investors and promoting hydrocarbon exploration. In parallel, hydrocarbon shows (e.g. oil seeps) have been reported since 2005 along the Lukenie and Tshuapa rivers and along the shores of the Lake Inongo (lumps of bitumen on lake beaches). These were sampled and analysed by HRT Petroleum (Mello 2008), who identified them as remains of black oil generated by prolific and abundant source rocks. He further suggests that giant oil accumulations could have been formed: "The integration of all geological, geochemical and geophysical data available today suggests that the Cuvette Centrale Basin is an overcharged petroliferous basin that could be considered, today, one of the last provinces in Africa to hold giant to supergiant light oil, condensate and gas accumulations. The presence of oil seeps widespread around most of the Central Basin suggested a light oill gas prone system. The size of the structural highs, surpassing more than $1,000 \mathrm{~km}^{2}$ and, together with the presence of at least two active oil systems in most of the Basin, indicate that all elements and processes of the petroleum systems are active and works in the Basin."

More recently, the basin structure and source rock potential have been re-evaluated by reprocessing existing geophysical data (Kadima et al. 2011a, b) and re-analysing source rock samples stored at the RMCA (Sachse et al. 2012). In the light of these recent studies, Comico SPRL and Centrale Oil and Gas Ltd. asked GhGeochem for an independent review of existing geochemical data on source rocks and seeps (Harriman 2011) and the RMCA to organise in 2011 a new seeps sampling campaign to resample those visited by HRT Petroleum in 2007. The seeps were analysed by the same GhGeochem laboratory and the results compared and re-interpreted in the light of the previous results of HRT Petroleum (Harriman 2012).

\subsection{Tectono-Stratigraphic Evolution of the Congo Basin}

According to Daly et al. (1992) and Kadima et al. (2011a, b), the evolution of the CB started in the Neoproterozoic ( $700 \mathrm{Ma}$ ago), probably in an intracratonic extensional context. They suggested that subsequent subsidence during the Phanerozoic was, at least partly, related to the cooling of the stretched lithosphere and several episodes of basin inversion.

The general stratigraphic evolution has been synthesized by Lepersonne (1977), Lawrence and Makazu (1988) and Daly et al. (1992), based on the results of exploration projects, correlating well-logs with field-based observations along the basin margin (Verbeek 1970; Lepersonne 1977). A synthetic stratigraphic column was presented by Daly et al. (1992), assuming long-distance lateral continuity of the stratigraphic groups. However, this concept appears to be of limited applicability at basin scale, because the stratigraphic units vary laterally both in facies and thickness (Linol 2013; see also Linol et al., Chaps. 7-9 and 11, this Book). A revised and more detailed stratigraphy is presented in Kadima et al. (2011a; and Chap. 6 this Book), taking into account the spatial distribution of the observations (Fig. 18.2).

The development of the CB appears controlled by a series of tectonic events, defining three first-order tectono-stratigraphic units that are separated by prominent seismic reflectors, broadly correlated to the Neoproterozoic, Palaeozoic-Triassic and Jurassic-Cenozoic. Deposition was also controlled by variable climatic factors and changing paleogeographic position of Gondwana/Africa (Scotese 2009; Torsvik and Cocks 2011). The Gondwana continent, of which the Congo Shield formed a central place, was amalgamated at the Neoproterozoic-Palaeozoic transition (550-530 Ma), in a series of events defining the Pan-African orogeny (e.g. De Waele et al. 2008).

Sedimentation in the CB started in the Neoproterozoic during a phase of intracratonic rifting (Daly et al. 1992). This initial rift structure is consistent with aeromagnetic and gravity data (Chorowicz et al. 1990; see also Raveloson et al., Chap. 1, this Book) and might be connected laterally to the Sankuru-Mbuji-Mayi-Lomami-Lovoy failed rift basin that hosts the Meso- and Neoproterozoic Mbuji-Mayi Supergroup (1155 Ma to ca. $800 \mathrm{Ma}$; Delpomdor et al. 2013; and Delpomdor et al., Chap. 4, this Book). Post-rift subsidence controlled the deposition of a first sedimentary sequence during the Cryogenian and the Ediacaran (seismic unit A of Kadima et al. 2011a; Delpomdor et al., Chap. 4, this Book). This sequence is part of the type Lindian Supergroup described by Henry (1922-1923), Sluys (1945) and Verbeek (1970) in the Lindi-Aruwimi region, north of Kisangani (Fig. 18.1). In this Lindian type region, it comprises $\sim 130 \mathrm{~m}$ of stromatolitic carbonates at the base (Ituri Group), followed by $\sim 470 \mathrm{~m}$ of siliciclastics and limestone (Lokoma Group) deposited in an environment interpreted as lagoonal to marine (Verbeek 1970). The Ituri Group contains the Penge arkoses $(10-20 \mathrm{~m})$, Lenda carbonates with carbonaceous layers $(80-130 \mathrm{~m})$ and Asoso shales and sandstones $(50 \mathrm{~m})$. The Lokoma Group comprises the Akwokwo tillites $(0-40 \mathrm{~m})$, the Bobwamboli conglomerates and arkoses $(50-250 \mathrm{~m})$, the Mamungi grey shales and limestones (200-500 m) and the Kole shales $(100 \mathrm{~m})$.

In the Lindi-Aruwimi region (Fig. 18.1), the Ituri Group is unconformably overlain by up to $2,000 \mathrm{~m}$ thick siliciclastics (Aruwimi Group: Verbeek 1970; Tait et al. 2011). This possibly forms the base of seismic unit $B$ of Kadima et al. (2011a) in the centre of the CB. In outcrop, it is 


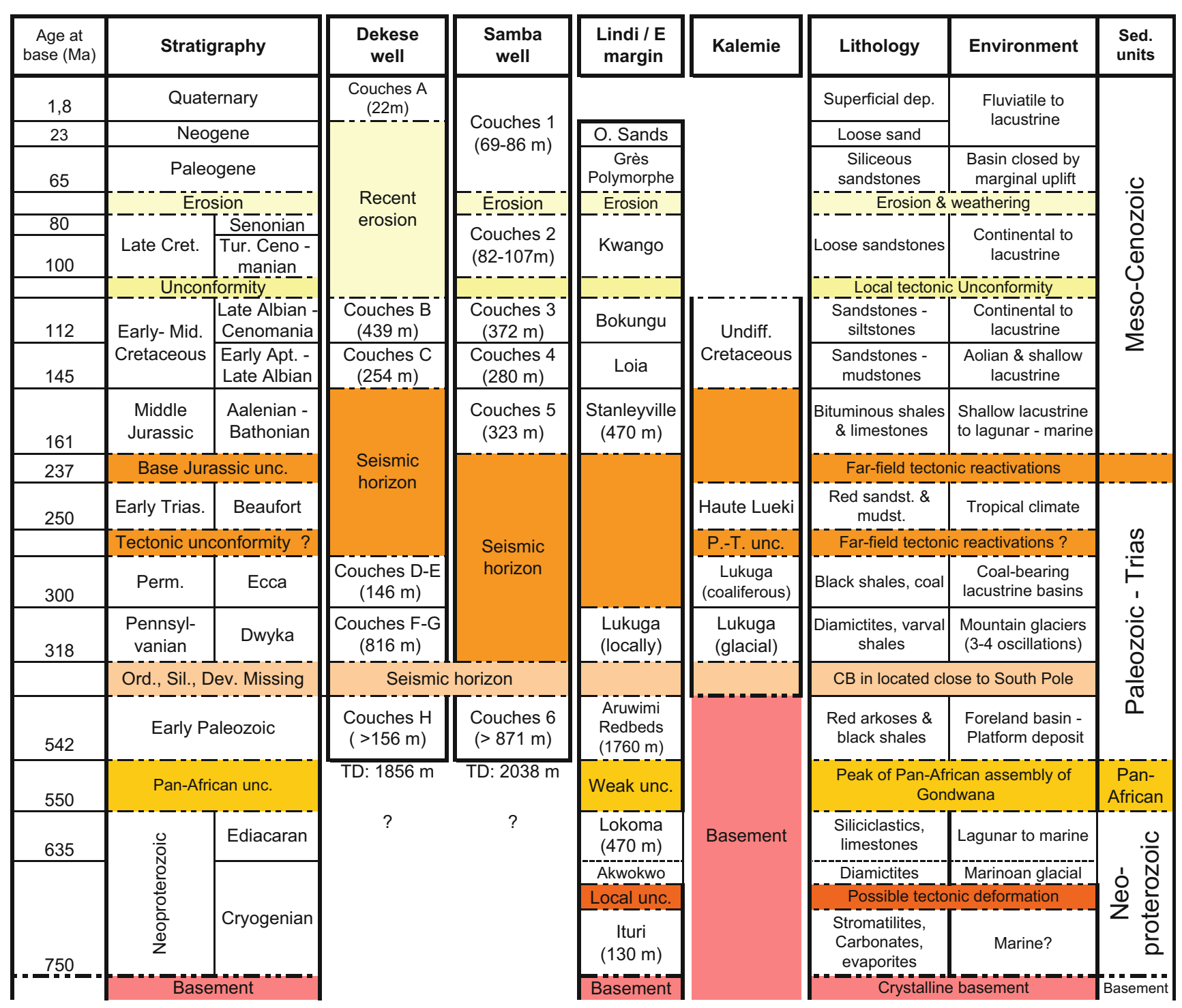

Fig. 18.2 Schematic lithostratigraphy of the Congo Basin (modified from Kadima et al. 2011a), based on the two stratigraphic wells (Samba and Dekese) and outcrop data in in the northeastern and eastern margins of the basin

subdivided successively from base to top into: the Galamboge arkoses and quartzites $(100-150 \mathrm{~m})$; the Alolo dark carbonaceous shales (350-400 m); and the Banalia red arkoses (up to $1,200 \mathrm{~m}$ ), with $\sim 100 \mathrm{~m}$ thick transitional units between them (Verbeek 1970). The Alolo shales are interpreted to have been deposited in a shallow marine to lagoonal basin (Verbeek 1970). The Aruwimi Group is tentatively correlated to the Inkisi post Pan-African fluviodeltaic red sandstones in the West Congo Belt (Alvarez et al. 1995; Tait et al. 2011), the Biano red sandstones in the Kundelundu foreland of the Katanga Fold Belt (Kampunzu and Cailteux 1999) and the red sandstones of the lower parts of the Samba and Dekese wells (Cahen et al. 1959, 1960). Using refractions seismic velocities, Evrard (1960) recognized the similarity between the red sandstones in the lower part of the Samba and Dekese wells, but did not exclude that they could be younger than the red sandstones of the Aruwimi, Inkisi and Biano Groups. This correlation is based on lithological similarity (quartzitic red sandstones), taking also into consideration the fact that these series are all post-orogenic relative to the Pan-African deformation. In the Dekese well, the red sandstones are overlain by glacialinterglacial and post-glacial sediments of the Lukuga Group (from the depths of $816 \mathrm{~m}$ and $146 \mathrm{~m}$, respectively), dated to be Late Carboniferous-Permianin age (Cahen et al. 1960; Boze and Kar 1978; Cahen and Lepersonne 1978). The age of the Aruwimi Group is therefore constrained only by a regional unconformity at the base, and by the Upper Paleozoic sediments of the Lukuga Group on top, spanning the entire Early-Middle Paleozoic. No prominent 
discontinuities can be seen between the Aruwimi and the Lukuga Groups, either in the Dekese core or in the seismic profiles. However, a sedimentary hiatus may exist between the two, corresponding to the Ordovician-Early Carboniferous period during which Gondwana drifted across the South Pole (located, respectively, in Algeria in Early Ordovician, in Guinea in Late Ordovician, in Angola in Late Devonian, in northern DRC in Early Carboniferous, in South Africa in Mid Carboniferous, and Antarctica in Late Carboniferous; e. g. Torsvik and Cocks 2011).

The Lukuga Group contains a series of glacial to periglacial massive diamictites and varval dark grey shales in the Dekese core (couches F-G of Cahen et al. 1960), interpreted to be deposited in a large basin adjacent to mountain systems, or as moraine deposits in paleo-glacial valleys outcropping in East DRC. They are overlain by postglacial brown sandstones and shales in the Dekese core (couches D-E of Cahen et al. 1960), or sandstones with coal seams in the Kalemie region along the western shore of Lake Tanganyika (Fig. 18.1), in the Lukuga coal field (Fourmarier 1914; Jamotte 1931; Cahen and Lepersonne 1978). In the latter locality, fossiliferous reddish sandstones and mudstones of the Lower Triassic Haute Lueki Group overly with a local unconformity Permian sediments (Jamotte 1931; Cahen and Lepersonne 1978). The Triassic has not been formally recognized in the Samba and Dekese wells, but might be present in reduced thickness in the Dekese well above the Lukuga Group (Linol 2013; see also Linol et al., Chap. 7, this Book). Linol (2013) also proposed that the red arkoses of the Samba core could be of Triassic age. In absence of chronological evidence (to date, no spore and pollens or other fossils have been found), we support the views of Cahen et al. (1959) who correlated the red sandstones of the Samba well to the Aruwimi, Inkisi and Biano Groups (Fig. 18.2). Cahen et al. (1959) also mentioned that undetermined organic material was found in one place. This would suggest that the red sandstones are younger than Ordovician. But in their conclusion, Cahen et al. (1959) did not take into account this observation as an age constraint.

A subsequent regional unconformity separates the Paleozoic (and possibly also the Triassic) from the overlying Jurassic-Cretaceous and Cenozoic successions that comprise a third sedimentary unit (Fig. 18.5, seismic unit $\mathrm{C}$ of Kadima et al. 2011a; Linol et al., Chaps. 8, 9 and 11 this Book). Its base is defined by the Stanleyville Group, which is exposed along the upper course of the Congo River (locally named Lualaba), south of Kisangani (Fig. 18.1), with up to $470 \mathrm{~m}$ of lacustrine sandstones with organic-rich shales and some limestone (Passau 1923; Sluys 1952; Grecoff 1957; Cox 1960; Lombard 1960; Lepersonne 1977; Cahen 1983a; Colin 1994). Towards the basin centre, in the Samba well, $323 \mathrm{~m}$ of fluvial-lacustrine red sandstones with thin layers of bituminous shales are also attributed to the Stanleyville Group; here they directly overlie the red arkoses attributed to the Aruwimi Group (Couches 5; Cahen et al. 1959). In contrast, the Stanleyville Group was not recognized in the Dekese well (Cahen et al. 1960) but it occurs in a condensed section in the Kinshasa area (Egoroff and Lombard 1962; Defrétin-Lefranc 1967). The depositional environment of the Stanleyville Group is generally interpreted as lacustrine (Grecoff 1957; Cox 1960; Cahen 1983a; Colin 1994). A limited marine influence was initially suggested by de Sainte Seine and Casier (1962) on the basis of fossil fishes found near the base of the Stanleyville Group. After a paleoichthyological study, Taverne (1975a, b, and personal communication, 2014), however, no clear evidence for a marine influence during deposition of the Stanleyville Group. A Kimmeridgian age was proposed by de Sainte Seine (1955) on the basis of fossil fishes, but Colin (1994), on the basis of palynological and micropaleontological evidence, considered it as Middle Jurassic (AalenianBathonian).

After a long depositional hiatus, the succeeding Middle Cretaceous Loia and Bokungu Groups were deposited across the central CB (Lepersonne 1977; Maheshwari et al. 1977; Cahen 1983b). The Loia Group (Late Aptian-Early Albian; after Colin 1981) was first recognized in the Dekese well by254 $\mathrm{m}$ of aeolian sand dunes (Couches $\mathrm{C}$ of Cahen et al. 1960; Linol 2013) and in the Samba well, by $280 \mathrm{~m}$ of shallow lacustrine sandstones and mudstones with a few thin black shale levels (Cahen et al. 1959, 1960). According to the more recent chronostratigraphic correlations of Linol (2013; Linol et al., Chaps. 8 and 11, this Book), the aeolian sand unit (the Dekese Formation) is Late Jurassic-Early Cretaceous and not part of the Middle Cretaceous, reducing part of the hiatus between the Stanleyville and the Loia Groups. The Bokungu Group (Late Albian, after Colin 1994), with fluvio-deltaic sandstones and siltstones $(372-439 \mathrm{~m})$, is unconformably overlain by unconsolidated siliceous sandstones of the Cenomanian Kwango Group $(250-280 \mathrm{~m})$. The Paleogene is represented by the Grès Polymorphe Formation (Eocene, after Colin 1994) comprising silicified sands covering a prominent erosion surface, and in turn by the Neogene 'Ochre Sands' (70-90 m in total for the Cenozoic; Cahen et al. 1959, 1960; Cahen 1983b; Lepersonne 1977).

This above summary demonstrates that the sedimentary sequences display distinct lateral thickness and facies variations at the basin scale. It highlights also some disagreements about their age (e.g. Lower Paleozoic versus Triassic for the red quartzites in Samba). Specifically, locally angular discontinuities between the seismic packages B and C (not shown here) range at least from the Early Paleozoic to the Early Jurassic in the Samba well, and from the Late Triassic to Early Cretaceous in the Dekese well; and is almost absent 
in the Kalemie area. This loosely constrains an important compressional basin inversion event that Daly et al. (1992) related to far-field effects of the Late Permian-Triassic development of the Cape Fold Belt inSouth Africa (Halbich et al. 1983; Le Roux 1995; Delvaux 2001; Newton et al. 2006; Tankard et al. 2009).

The lateral facies changes across the basin make correlation between the different stratigraphic packages difficult. This is particularly the case for the pre-Jurassic successions (ca. $3 \mathrm{~km}$ thick) encountered in the Mbandaka-1 and Gilson-1 wells above the Neoproterozoic carbonates. As a consequence, stratigraphic correlations of the Paleozoic to Triassic sequences of the CB (Daly et al. 1992; ECL 1988; ESSO Zaire 1981a, b; Kadima et al. 2011a and other unpublished reports; Linol et al., Chap. 7, this Book) differ each other. This is mainly caused by the lack of chronostratigraphic control for this large part of the basin fill. By contrast, the age of the overlying Jurassic to Neogene sequences and the underlying Neoproterozoic carbonates are better constrained.

\subsection{Potential Source Rocks}

Several potential source rocks have been recognised in the $\mathrm{CB}$ at different stratigraphic levels and locations, but with relatively limited lateral continuity (at the scale of the basin). These are listed below, together with their age estimations:

- Mamungi greyshales of the Lokoma Group (Neoproterozoic)

- Alolo dark shales of the Aruwimi Group in the Aruwimi River region north of Kisangani (Early to Middle Paleozoic)

- Lukuga peri-glacial grey-shales in the Dekese well, and post-glacial coal measures in the Kalemie and Upemba coal fields, respectively, along Lake Tanganyika and in the Kibara Belt in North-Katanga (Late CarboniferousPermian);

- Stanleyville Group with black shales along the Congo River upstream Kisangani (Lualaba) but red sand and siltstones in the Samba well (Middle or Upper Jurassic);

- Loia Group with seven thin lacustrine black shales levels in the Samba well;

- Kipala black shales south of the Kasai River (Upper Cretaceous, Kwango Group).

The petroleum potential and maturation estimates of these source rocks were initially based on a limited number of organic matter analyses from a selection of samples of core and outcrops, stored at the RMCA. First generation of Rock-Eval instruments (RRI 1988) were used for the analyses. JNOC (1984) also performed a number of analyses on separate outcrop samples, mainly from the Loia and Stanleyville organic-rich shales, but we were not able to re-locate the samples on maps. New petrological and geochemical analyses (Total Organic Carbon $\left(\mathrm{C}_{\text {org }}\right)$, RockEval and Gas Chromatography - Mass Spectrometry) were undertaken by Sachse et al. (2012) on a large number of Palaeozoic and Mesozoic outcrop and core samples from the Dekese and Samba wells. The JNOC Rock-Eval results are reported in Table 18.1. The analysis of the RMCA samples [RWTH data of Sachse et al. (2012) and two data from Kadima (2007)] are reported in Table 18.2. The results, averaged for each stratigraphic unit, are given in Table 18.3.

The type of kerogen in the sediment is characterized using the Rock-Eval results on a Van-Krevelen equivalent diagram (Espitalie et al 1977), by the Hydrogen Index (mg $\mathrm{HC}$ equivalents/g $\mathrm{C}_{\mathrm{org}}$ ) and Oxygen Index ( $\mathrm{mg} \mathrm{CO} 2 / \mathrm{g} \mathrm{C}_{\text {org }}$ ). On such diagram (Fig. 18.3) different kerogen types are shown to follow different evolution paths depending on thermal maturation. Progressive decrease in Hydrogen and Oxygen index values reflects loss of hydrocarbon chains and oxygenated functions (Tissot and Welte 1978). Kerogen type I is typical lacustrine organic-matter, rich in aliphatic chains and poor in aromatics, derived from algal lipids, or enriched by microbial activity. Kerogen type II is richer in aromatics, which is usually attributed to marine organic matter deposited in a reducing environment, but which can also correspond to a combination lacustrine algae (type I) and terrestrial (type III) organic matter. Kerogen type III is rich in aromatics and oxygenated functions and is derived from terrestrial higher plants. Organic matter unable to generate oil or gas is qualified as Type IV kerogen. Results of the RMCA samples analyzed by RWTH Aachen (Sachse et al. 2012), with two samples of Kipala shales from Kadima (2007) are shown in Fig. 18.3a, and the JNOC samples (JNOC 1984), in Fig. 18.3b. Sachse et al. (2012) further studied the organic matter by organic petrology and molecular organic geochemistry. Combined with the total organic matter content $\left(\mathrm{C}_{\text {org }}\right)$ and Rock-Eval parameters, this allowed the following characterization of the different source rock horizons (Table 18.3):

- Samples of the Alolo shales from the Aruwimi Group are in general very low in $\mathrm{C}_{\text {org }}(<0.2 \%$ in average), and contain a high amount of degraded organic matter. They are considered barren. Samples from the Yambuya section are slightly richer $(0.58 \%$ in average) but few of them are rich enough to allow Rock-Eval analysis; which in any case released very little quantities of hydrocarbon during pyrolysis, but high quantities of $\mathrm{CO}_{2}$ (very low $\mathrm{HI}$ and high OI). They contain a type III/IV kerogen and cannot be considered as a potential source rock. Similarly, an Alolo shale sample taken during the 2011 CoMiCo-RMCA field survey is almost devoid of organic matter (0.08 \% $\mathrm{C}_{\text {org. }}$, Harriman 2012), showing that oxidation of the organic matter during the 60 years storage cannot be invoked to explain these low values. 
Table 18.1 Organic matter analytical data (Total Organic Carbon and Rock-Eval) for the JNOC samples (from JNOC 1988)

\begin{tabular}{|c|c|c|c|c|c|c|c|c|c|c|c|}
\hline $\begin{array}{l}\text { JNOC } \\
\mathrm{Nr}\end{array}$ & Region & Group & Lithology & $\begin{array}{l}\text { Corg } \\
(\%)\end{array}$ & $\begin{array}{l}\mathrm{S} 1 \\
(\mathrm{mg} / \mathrm{g})\end{array}$ & $\begin{array}{l}\mathrm{S} 2 \\
(\mathrm{mg} / \mathrm{g})\end{array}$ & $\begin{array}{l}\mathrm{S} 3 \\
(\mathrm{mg} / \mathrm{g})\end{array}$ & $\begin{array}{l}\mathrm{HI}(\mathrm{mg} / \mathrm{g} \\
\text { Corg) }\end{array}$ & $\begin{array}{l}\text { OI }(\mathrm{mg} / \mathrm{g} \\
\text { Corg) }\end{array}$ & $\begin{array}{l}\text { Tmax } \\
\left({ }^{\circ} \mathrm{C}\right)\end{array}$ & $\begin{array}{l}\mathrm{Vr} \\
(\%)\end{array}$ \\
\hline KS-26 & Kisangani & \multirow[t]{17}{*}{ Stanleyville } & \multirow[t]{17}{*}{ Oil shales } & 10.1 & 0.54 & 108.1 & 2 & 1.067 & 20 & 435 & \\
\hline KS-28 & Kisangani & & & 12 & 0.84 & 125.4 & 2.24 & 1.043 & 19 & 432 & \\
\hline KS-32 & Kisangani & & & 5.55 & 0.1 & 58.4 & 1.77 & 1.052 & 32 & 433 & \\
\hline KS-33 & Kisangani & & & 5.02 & 0.22 & 59.4 & 1.1 & 1.183 & 22 & 435 & \\
\hline KS-34 & Kisangani & & & 6.21 & 0.21 & 72 & 1.24 & 1.159 & 20 & 437 & \\
\hline KS-35 & Kisangani & & & 0.92 & 0.03 & 3.97 & 0.52 & 432 & 57 & 429 & \\
\hline KS-36 & Kisangani & & & 1.24 & 0.06 & 6.43 & 0.71 & 519 & 57 & 430 & \\
\hline KS-38 & Kisangani & & & 9.23 & 0.2 & 118.7 & 1.48 & 1.286 & 16 & 439 & \\
\hline KS-45 & Kisangani & & & 15.5 & 2.58 & 172 & 3.16 & 1.112 & 20 & 422 & \\
\hline KS-46 & Kisangani & & & 16.2 & 1 & 169 & 3.44 & 1.041 & 21 & 435 & \\
\hline KS-47 & Kisangani & & & 17.6 & 0.94 & 169.3 & 2.18 & 960 & 12 & 437 & \\
\hline KS-48 & Kisangani & & & 1.63 & 0.13 & 5.59 & 1.38 & 343 & 85 & 434 & 0.85 \\
\hline KS-52 & Kisangani & & & 9.61 & 0.22 & 108.4 & 2.66 & 1.128 & 28 & 438 & \\
\hline KS-81 & Kisangani & & & 5.48 & 0.51 & 45.04 & 2.11 & 822 & 39 & 427 & 0.69 \\
\hline KS-82 & Kisangani & & & 2.8 & 0.21 & 25.06 & 0.98 & 895 & 35 & 429 & \\
\hline KS-83 & Kisangani & & & 1.24 & 0.03 & 5.45 & 0.4 & 440 & 32 & 433 & \\
\hline KS-84 & Kisangani & & & 8.23 & 1.82 & 98.24 & 1.51 & 1.194 & 18 & 432 & \\
\hline KS-18 & Kisangani & \multirow{6}{*}{ Stanleyville } & \multirow{6}{*}{$\begin{array}{l}\text { Limestones \& calcareous } \\
\text { shales }\end{array}$} & 0.38 & 0.03 & 0.65 & 0.21 & 171 & 55 & 423 & \\
\hline KS-23 & Kisangani & & & 1.57 & 0.05 & 5.41 & 0.37 & 345 & 24 & 425 & \\
\hline KS-24 & Kisangani & & & 2.05 & 0.07 & 12.65 & 0.49 & 617 & 24 & 427 & \\
\hline KS-50 & Kisangani & & & 0.56 & 0.07 & 0.9 & 0.74 & 161 & 132 & 429 & \\
\hline KS-53 & Kisangani & & & 6.74 & 0.16 & 62.68 & 1.94 & 930 & 29 & 427 & \\
\hline KS-71 & Kisangani & & & 3.26 & 0.12 & 32.06 & 0.97 & 983 & 30 & 425 & \\
\hline KS-21 & Kisangani & \multirow{4}{*}{ Stanleyville } & \multirow[t]{4}{*}{ Mudstones } & 0.71 & 0.11 & 2.45 & 0.44 & 345 & 62 & 426 & \\
\hline KS-31 & Kisangani & & & 0.49 & 0.02 & 0.52 & 0.31 & 106 & 63 & 425 & \\
\hline KS-41 & Kisangani & & & 0.44 & 0.01 & 0.65 & 0.34 & 148 & 77 & 432 & \\
\hline KS-72 & Kisangani & & & 0.72 & 0.03 & 1.75 & 0.68 & 243 & 94 & 425 & \\
\hline KS-77 & Kisangani & \multirow{5}{*}{ Lukuga } & \multirow[t]{5}{*}{ Black varval shale } & 0.95 & 0.03 & 0.11 & 0.57 & 12 & 60 & 411 & 0.8 \\
\hline KS-78 & Kisangani & & & 1.02 & 0.03 & 0.14 & 0.43 & 14 & 42 & 453 & 0.5 \\
\hline KS-79 & Kisangani & & & 0.82 & 0.01 & 0.3 & 0.37 & 37 & 45 & 437 & 0.64 \\
\hline KS-87 & Kisangani & & & 1.42 & 0.01 & 0.16 & 1.18 & 11 & 83 & 434 & 0.48 \\
\hline KS-88 & Kisangani & & & 1.46 & 0.03 & 2.31 & 0.36 & 158 & 25 & 436 & 0.47 \\
\hline KS-104 & Kindu & \multirow[t]{2}{*}{ Lukuga } & \multirow[t]{2}{*}{ Black shale } & 0.61 & 0.01 & 0.24 & 0.41 & 39 & 67 & 435 & \\
\hline KS-105 & Kindu & & & 0.88 & 0.02 & 0.04 & 0.8 & 5 & 91 & 443 & 0.75 \\
\hline
\end{tabular}

Corg: total organic carbon; CaCO3: Carbonates; Rock-Eval pyrolysis parameters; S1: free/absorbed hydrocarbons, S2: hydrocarbons released by the pyrolysis of the kerogen, S3: oxygen-contained volatiles, hydrogen index (HI), oxygen index (OI), Tmax (temperature of the peak of S2 hydrocarbon generation during pyrolysis); vitrinite reflectance data (Vr)

- Samples from the Mamungi shales, Lenda carbonates and Bangu black limestones are all very poor in $\mathrm{C}_{\text {org, }}$,and considered barren.

- Permo-Carboniferous sediments from the Lukuga Group (Dekese well and outcrop samples) contain moderate contents of total organic carbon $\left(<=2.4 \% \mathrm{C}_{\text {org }}\right)$, with hydrogen-poor type III/IV gas-prone kerogen and a low hydrocarbon generation potential. They may have produced a limited amount of gas, but no oil.

- The Jurassic (Stanleyville Group) and Middle Cretaceous (Loia Group) samples from the Samba well, and outcrops in the north eastern part of the $\mathrm{CB}$, have up to $25 \% \mathrm{C}_{\text {org }}$. Sediments from the Stanleyville Group contain type I kerogen of excellent quality; and those of the overlying
Loia Group contain type I/II kerogen of good to excellent quality. They are derived from algae deposited in an aquatic anoxic environment, likely lacustrine, and contain small proportions of terrestrial type III material (Sachse et al. 2012).

- The Upper Cretaceous Kipala black shales are also excellent source rock $\left(\mathrm{C}_{\text {org. }}=8-9 \%\right.$, with ca. $\left.750 \mathrm{HI}\right)$ but are immature (Tmax $\left.=438-439^{\circ}\right)$ and of limited lateral extent. In summary, the new geochemical data confirm that the Stanleyville Group is the most promising source rock unit in the $\mathrm{CB}$, although it is immature. Samples from this group show a variety of organic matter content and composition, reflecting different depositional environments. In the Samba well, the Stanleyville Group comprises red siltstones and 


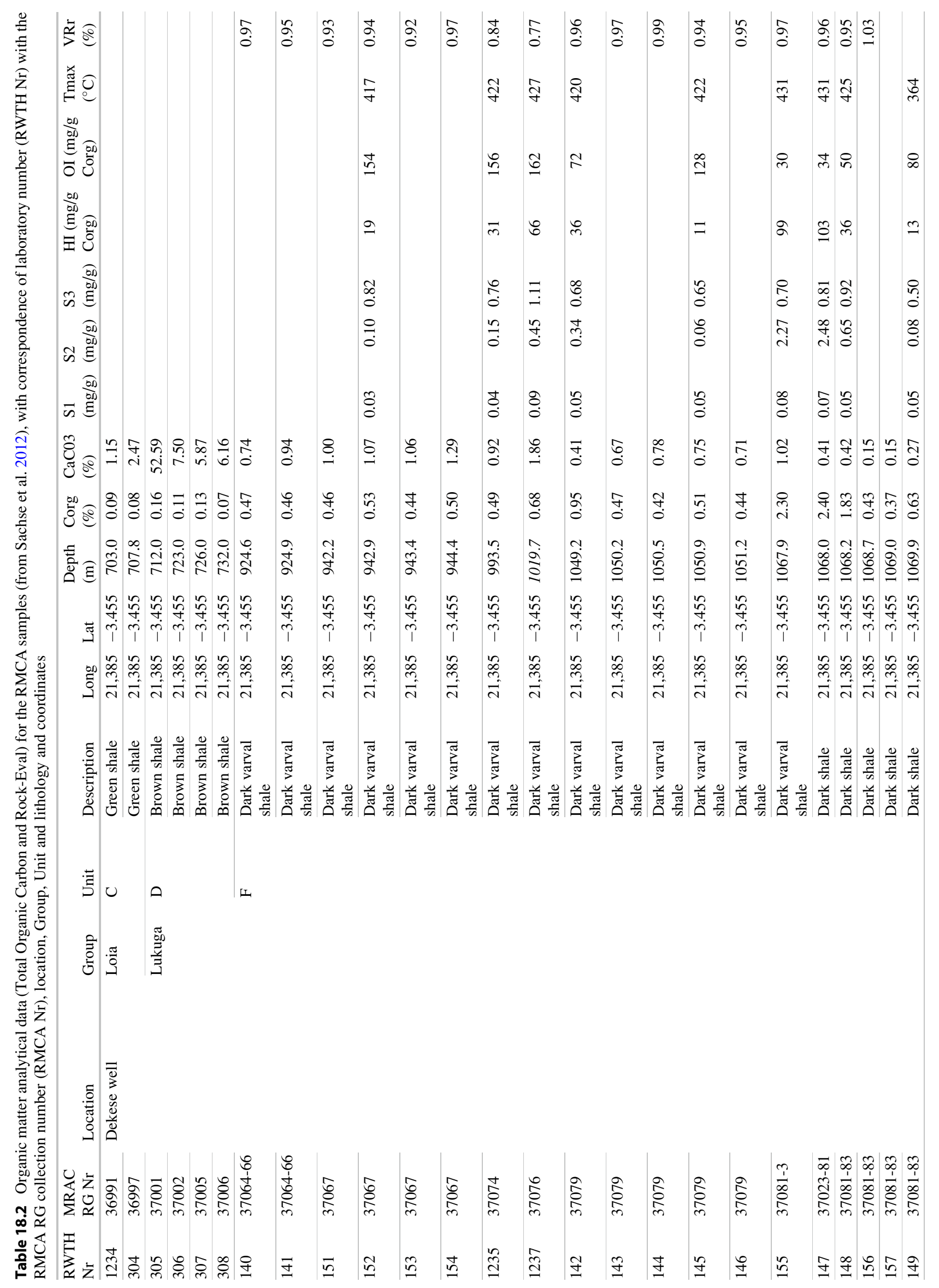




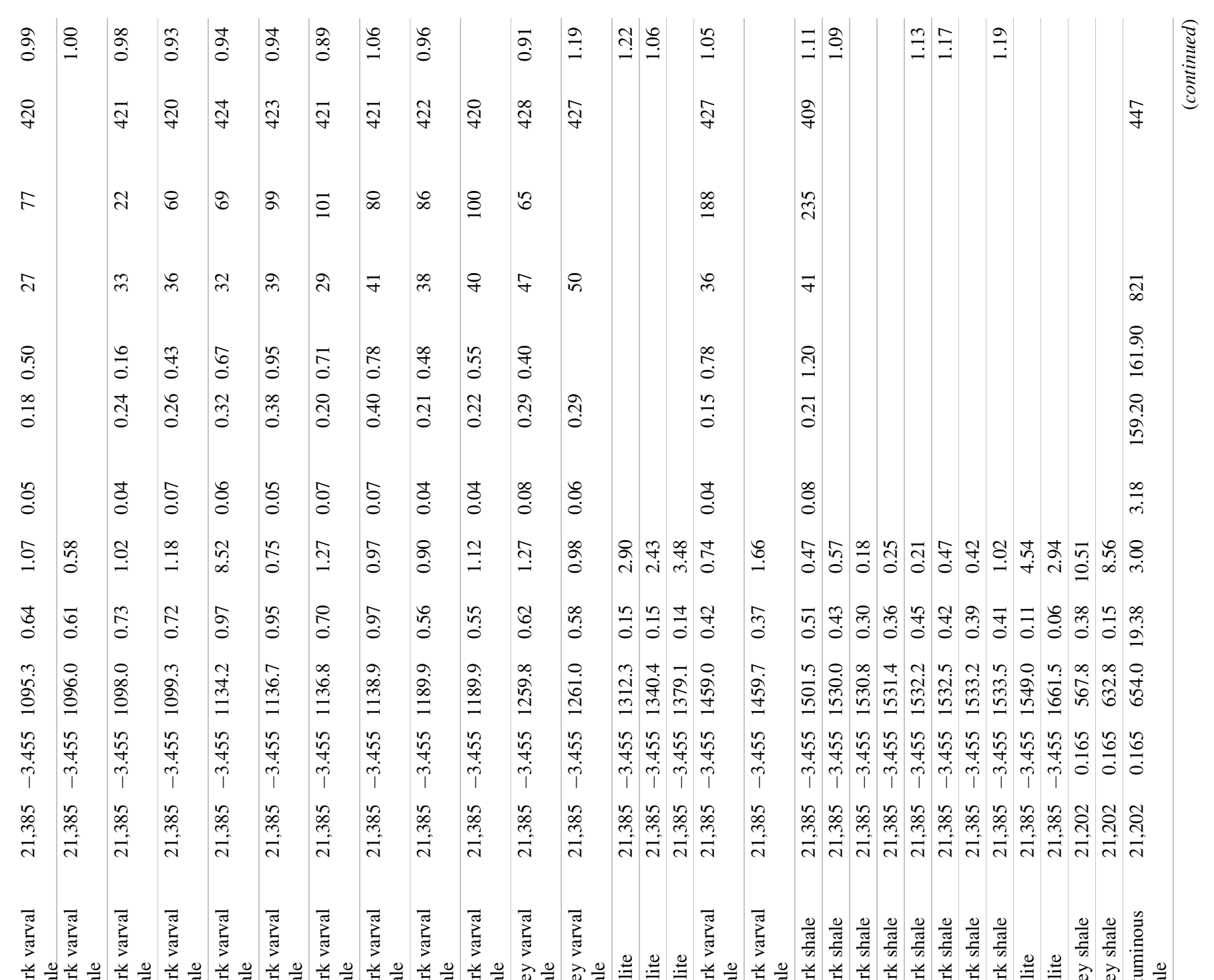

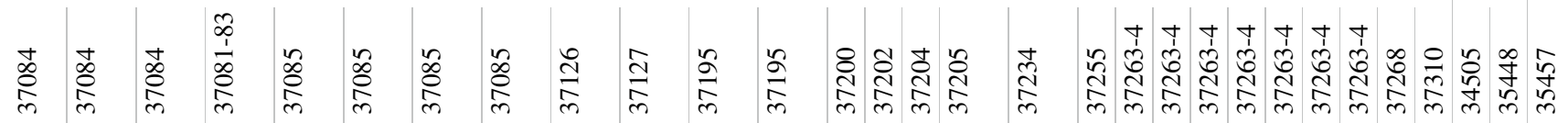

$\stackrel{\infty}{n}$ : 


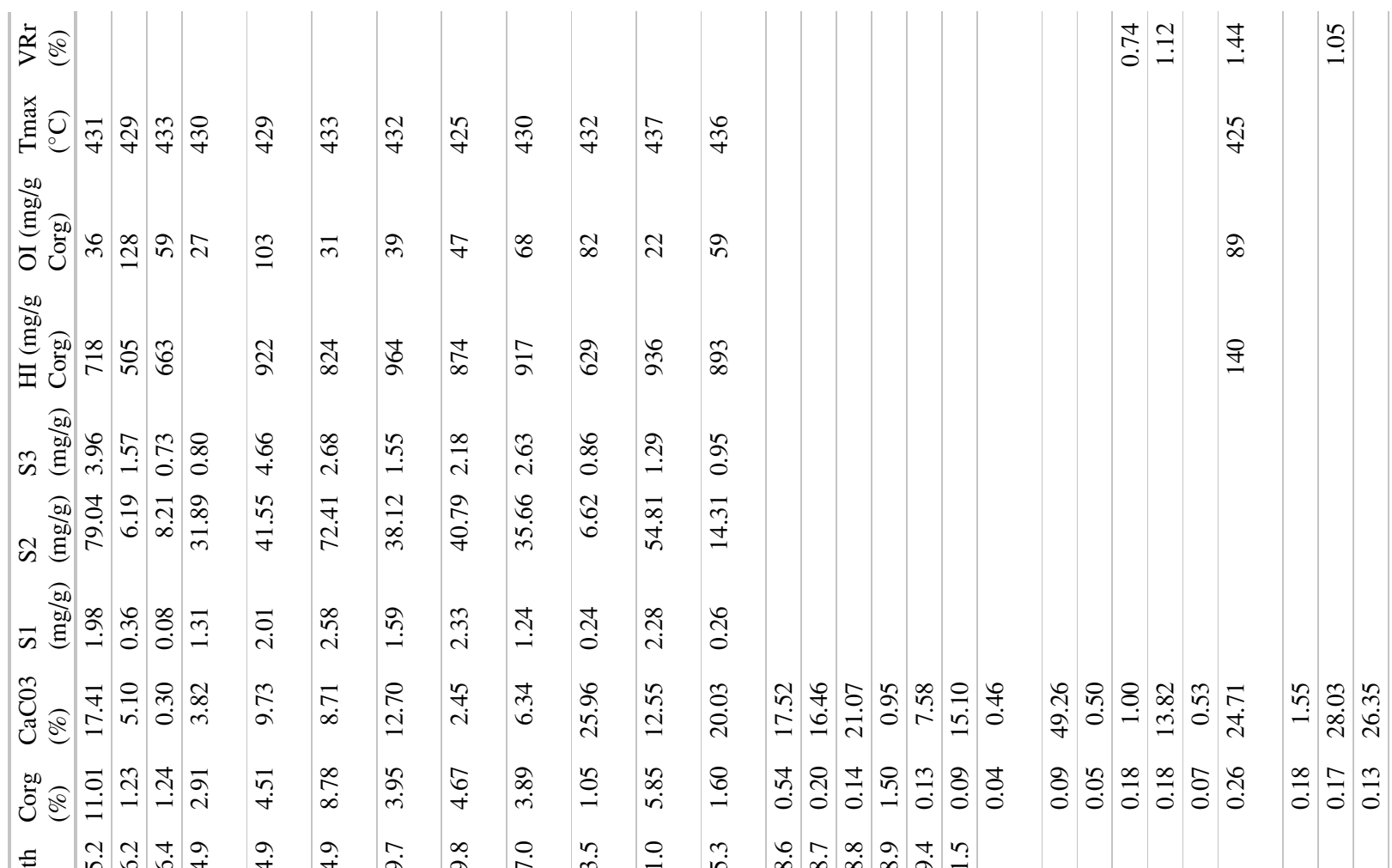

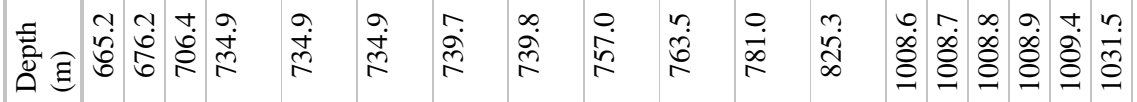

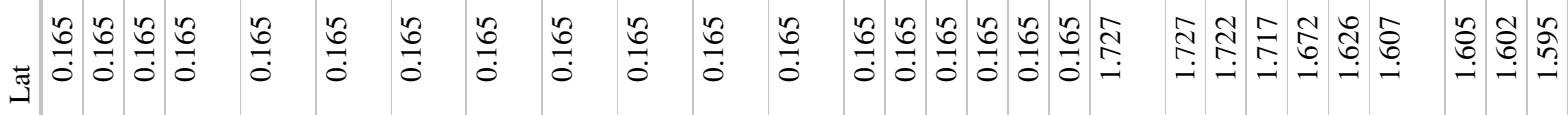

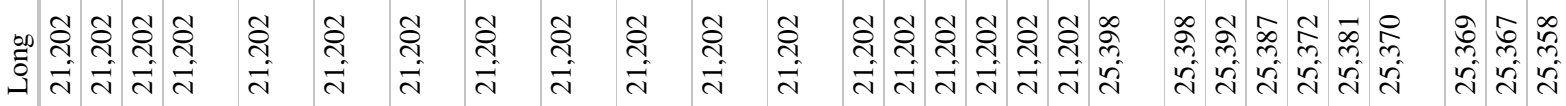

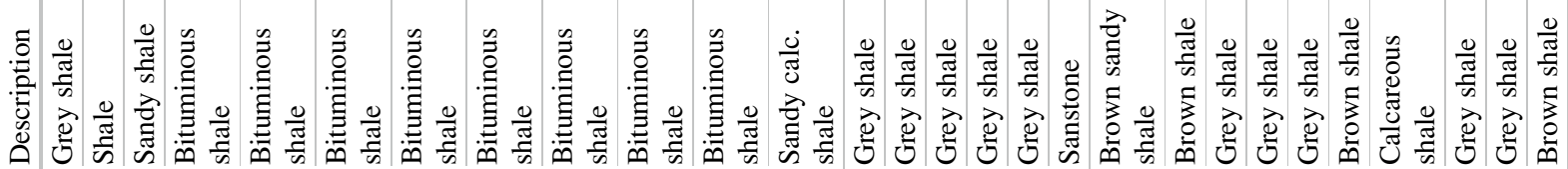

考

유ํ

తి

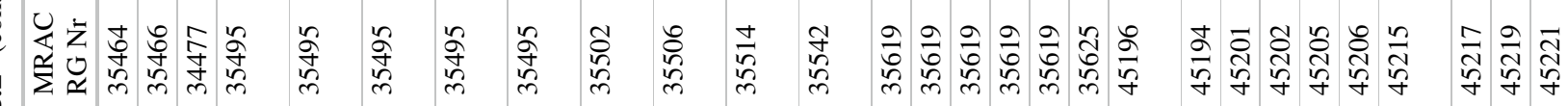

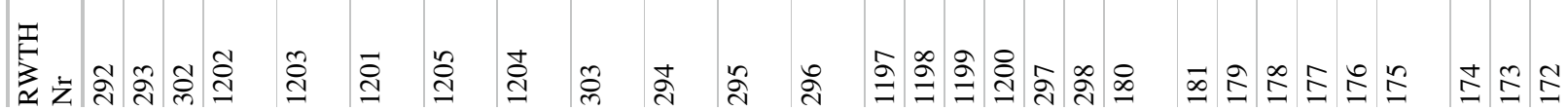




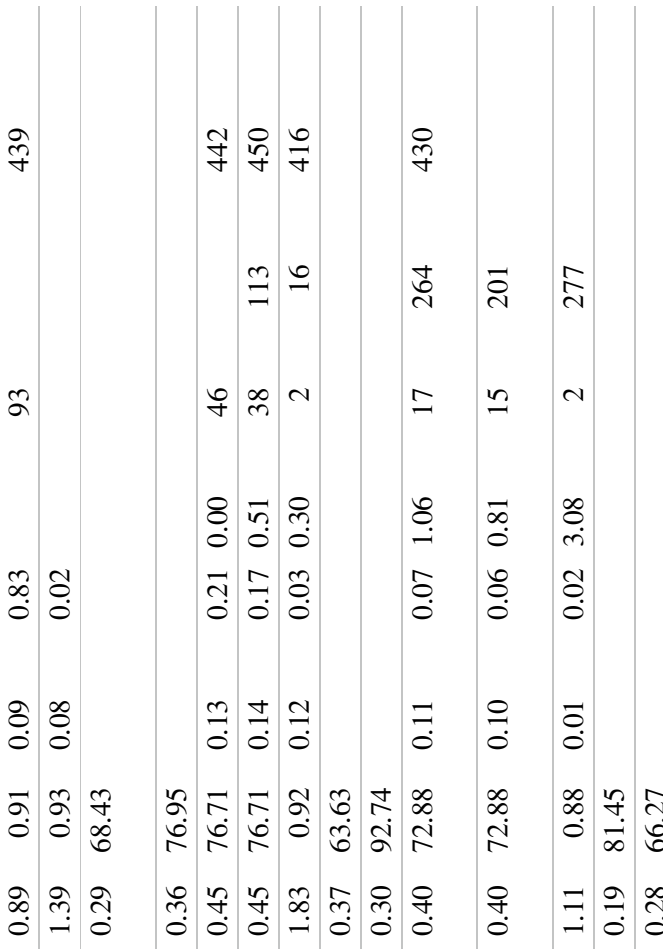

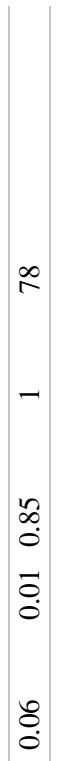

苞

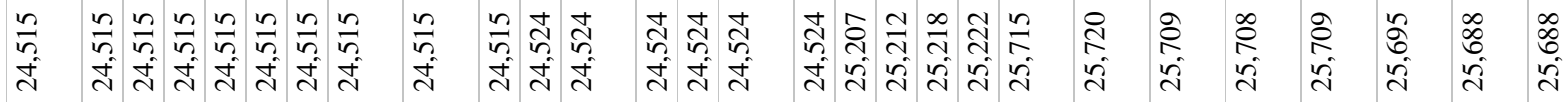

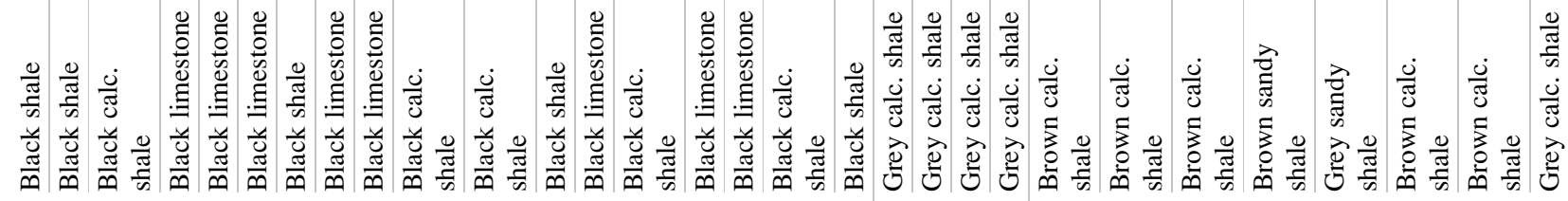

$\stackrel{\circ}{\stackrel{0}{<}}$

芩

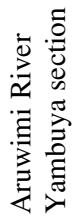

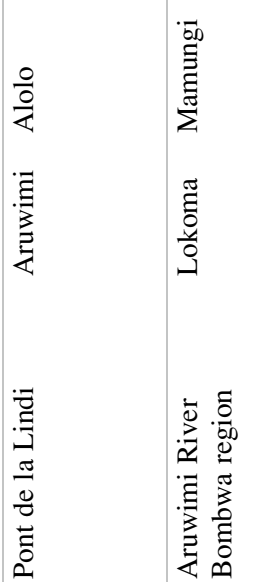

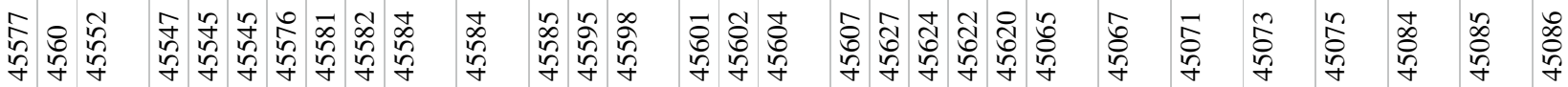

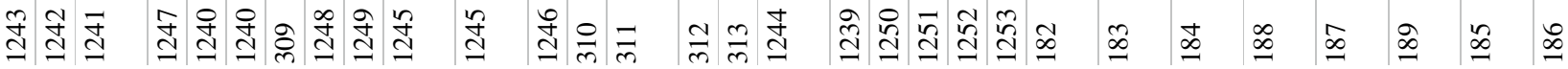




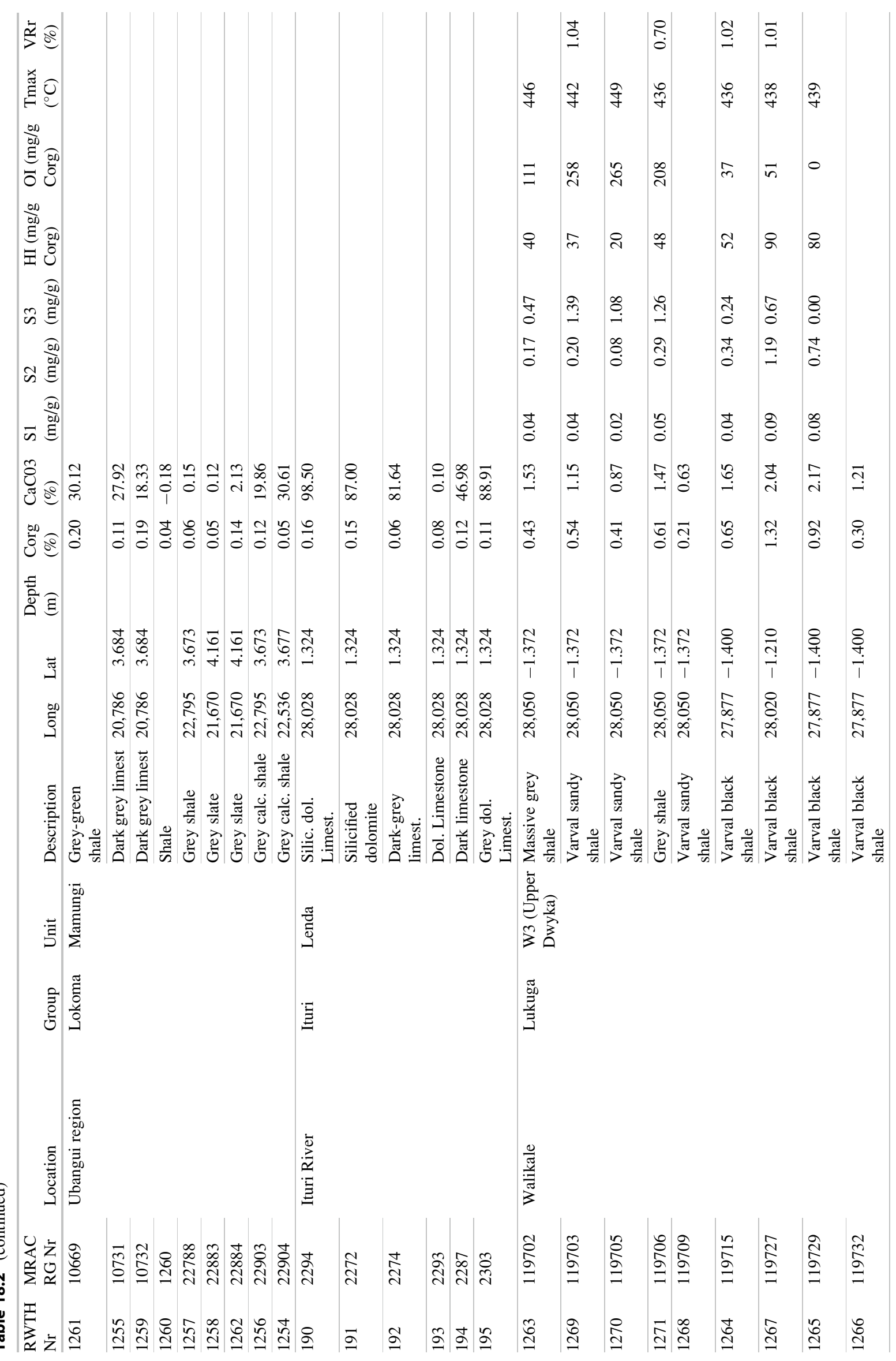




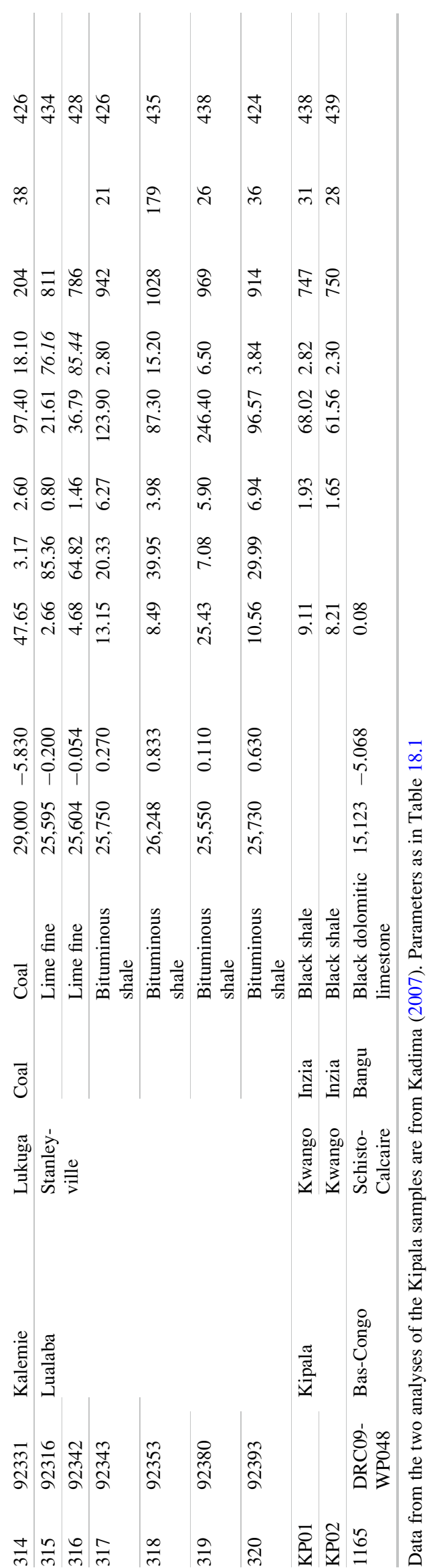




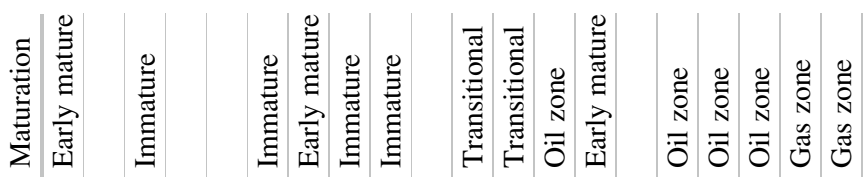

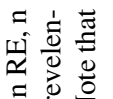

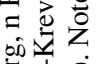

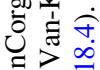

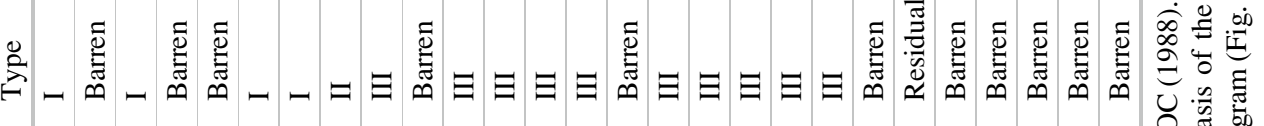

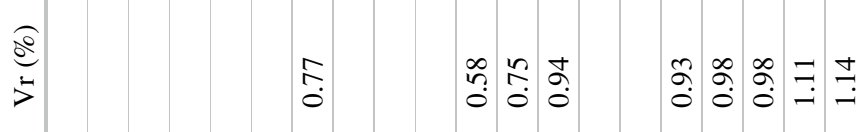

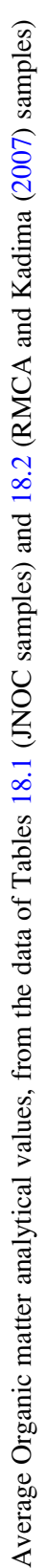

ठั)

है

ప్ర

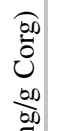

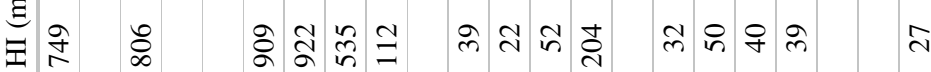

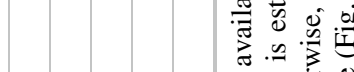

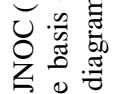

రิ

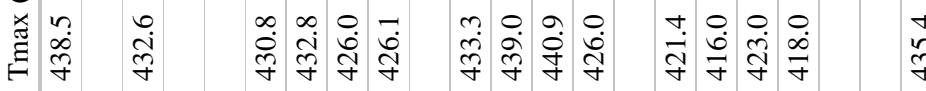

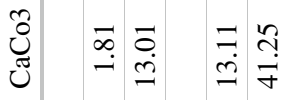

बे

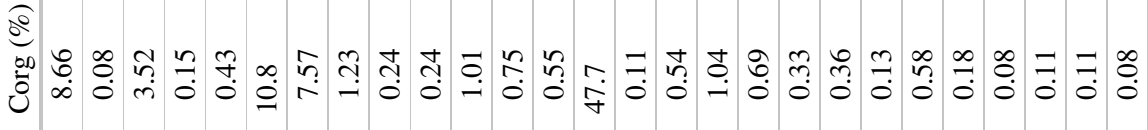

=

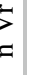

$\stackrel{1}{a}$

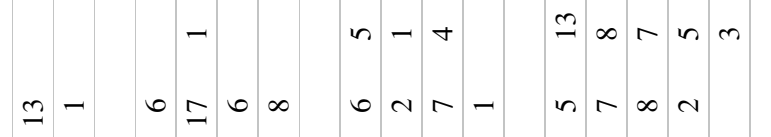

$\begin{array}{lllllll}0 & 0 & 0 & 0\end{array}$

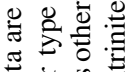

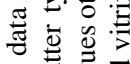

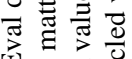

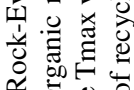

Oٓ

它

उ

它

过 䨔

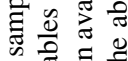

की ज्ञ

원원

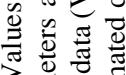

कo 跑

ठิ

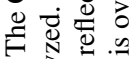

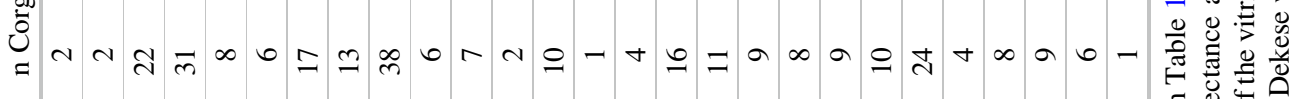

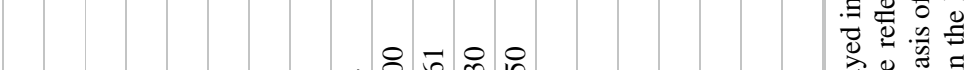

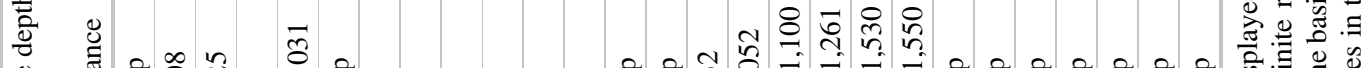

范

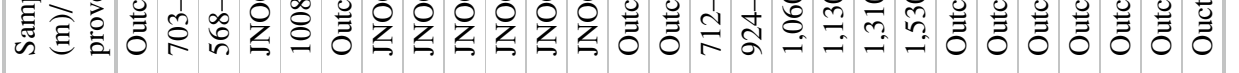

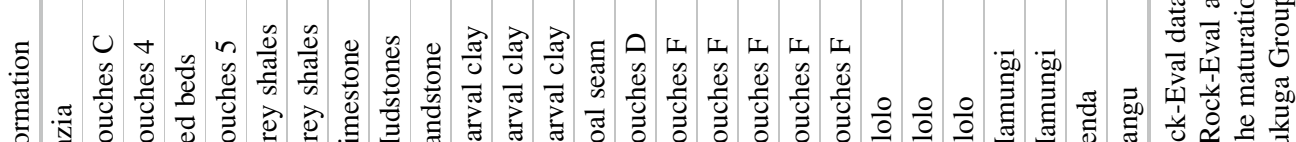

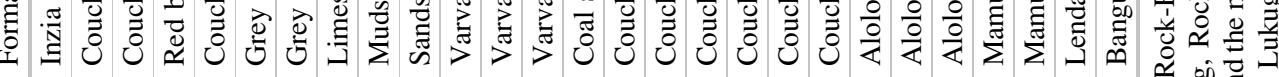

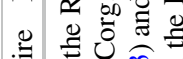

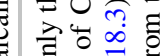

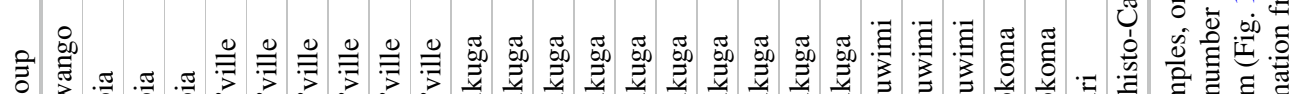

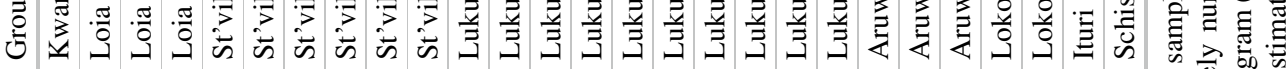

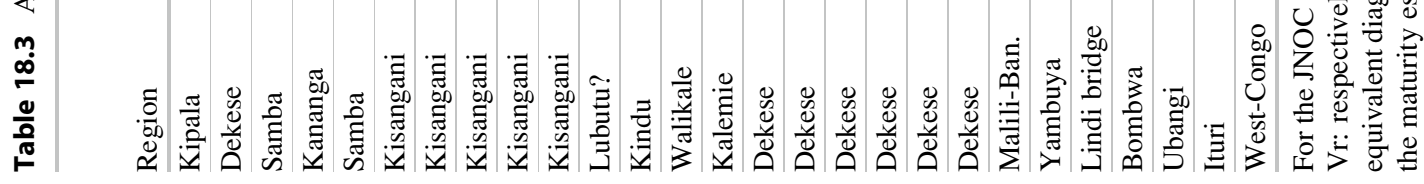


a

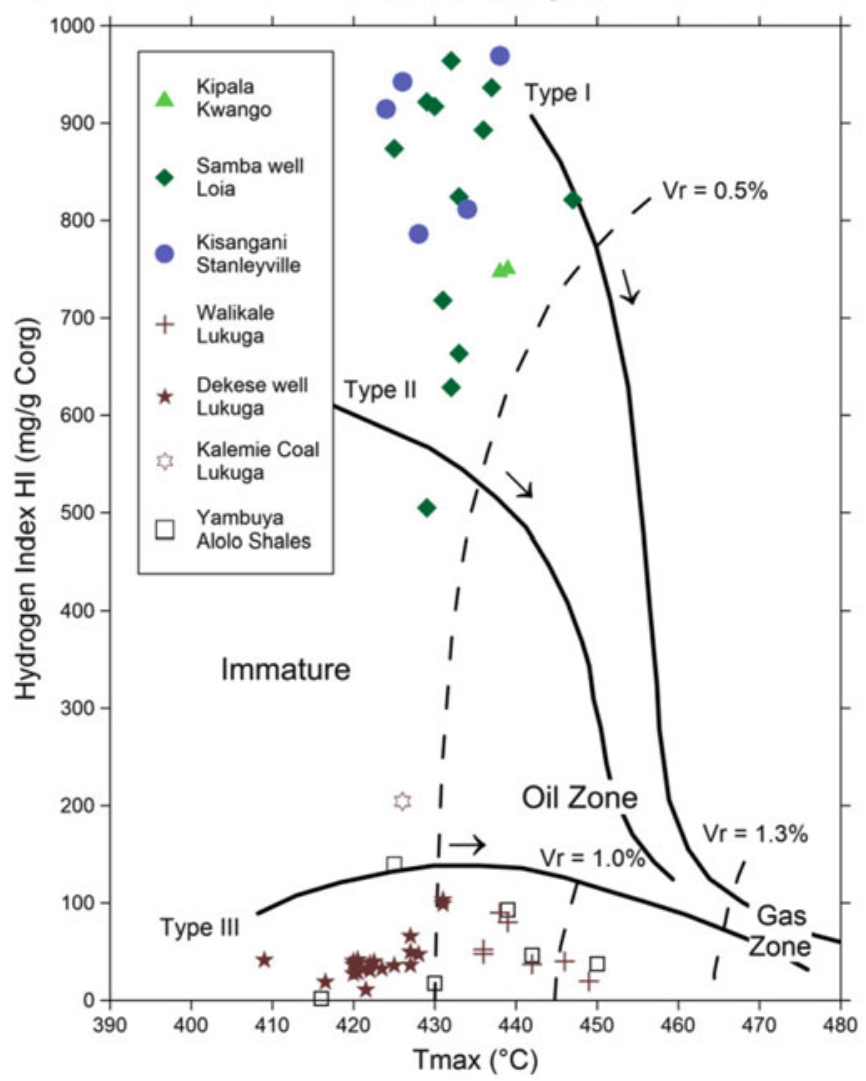

Fig. 18.3 Characterization of kerogen type on a Van-Krevelen equivalent diagram (Espitalie et al. 1977), using Rock-Eval Hydrogen and Oxygen indexes (HI and $\mathrm{HO}$ ). Bold lines show the evolution path of kerogen types with thermal maturation (along the direction shown by the arrows). Kerogen type I: rich in aliphatic chains and poor in aromatics, derived from algal lipids or enriched by microbial activity, typical of lacustrine organic-matter; type II: richer in aromatics, usually related to marine organic matter deposited on a reducing

sandstones and contain very little quantity of organic matter $\left(\mathrm{C}_{\text {org }}=0.43 \%\right.$, Table 18.3). The most organic-rich facies is the brown-grey shales (termed bituminous shales by Passau 1923), found in outcrops and boreholes from the KisanganiUbundu portion of the Congo River (Lualaba). Both the RMCA and the JNOC samples from this lithology are equally rich in $\mathrm{C}_{\text {org }}$, with ultra-high Hydrogen Index (900-1,000 mg HC equivalent/g $\mathrm{C}_{\text {org }}$ ) and a moderate to low Oxygen Index (30-70 mg CO2/g C $\mathrm{C}_{\text {org }}$ ). Some of the JNOC samples have anomalously high $\mathrm{HI}$ values $(>1,000)$, which likely reflects an analytical problem in isolating the inorganic from the organic carbon. Limestones are less rich in $\mathrm{C}_{\text {org }}$ (ca. 1-2 \%), but still with relatively high Hydrogen Index (500-600 mg $\mathrm{HC}$ equivalent/g $\mathrm{C}_{\text {org }}$ ). Mudstones and sandstones are poor to very poor in $\mathrm{C}_{\text {org. }}$. On the Van Krevelen-equivalent HI-OI diagram (Fig. 18.3), the samples of the Stanleyville Group display a range of compositions, from type I (algae) to type III (higher plant-derived) kerogen. b

JNOC samples

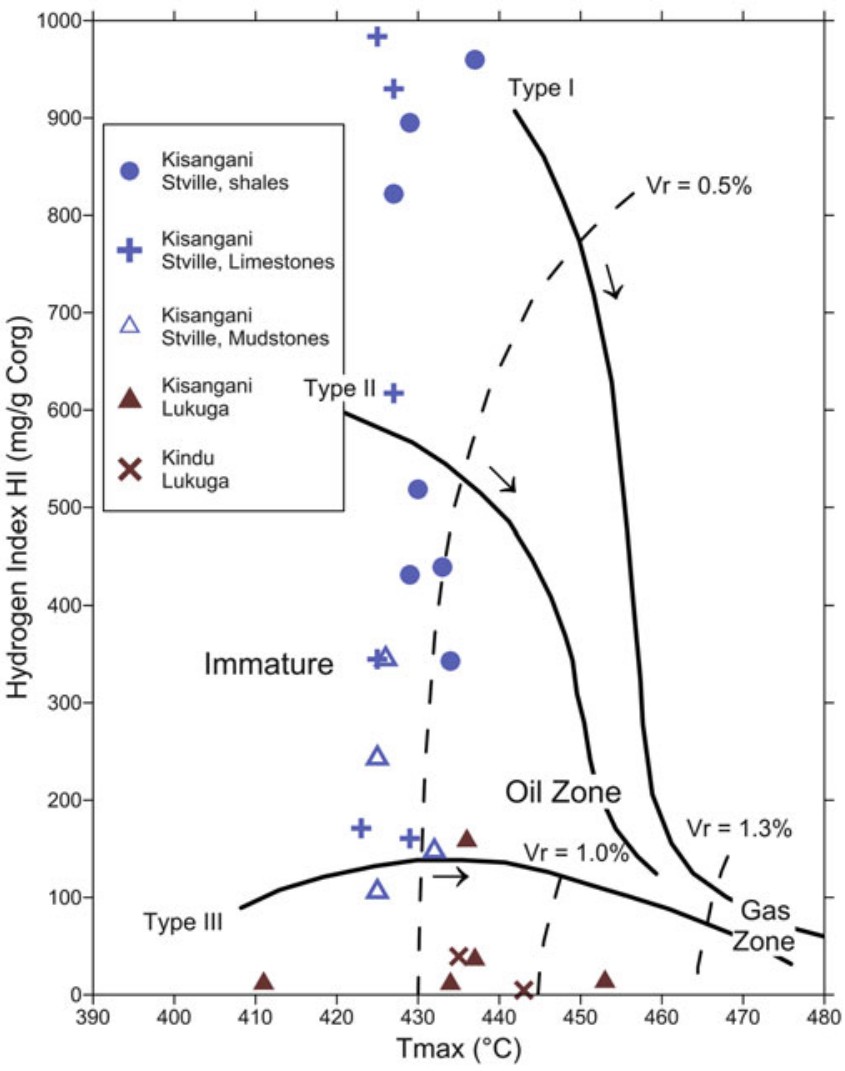

environment but also formed by a combination algae (type I) and terrestrial (Type III) organic matter, Type III: aromatics and oxygenated functions, derived from terrestrial higher plants (Tissot and Welte 1978). (a) RMCA samples, analyzed by RWTH Aachen (Sachse et al. 2012), with two samples of Kipala shales from Kadima (2007). (b) JNOC samples (JNOC 1984). Data from Tables 18.1 and 18.2

Similarly, samples of the Loia Group (Cretaceous) are rich in $\mathrm{C}_{\text {org }}$ in the Samba well (Couches 4 of Cahen et al. 1959), but very poor in the Dekese well (Couches $\mathrm{C}$ of Cahen et al. 1960) and in the region of Kananga (JNOC samples). Those from the Samba well display also high Hydrogen Indexes ( $\sim 800 \mathrm{mg} \mathrm{HC}$ equivalent/g $\mathrm{C}_{\text {org }}$ ) and medium Oxygen Indexes $\left(50-60 \mathrm{mg} \mathrm{CO} 2 / \mathrm{gC}_{\text {org }}\right)$.

Sulphur content, microscopic observations, n-alcane and biomarker patterns (Sachse et al. 2012) show that brown-grey shales of the Loia and Stanleyville Groups are composed predominantly of algae-derived aquatic organic matter and small amounts of terrestrial higher plant material. The range of composition of the Stanleyville samples analysed by JNOC (Fig. 18.3b) might therefore reflect various proportions of the endmembers (type I algae-derived and type III terrestrial higher plant-derived) rather than the presence of marine type II organic matter. 


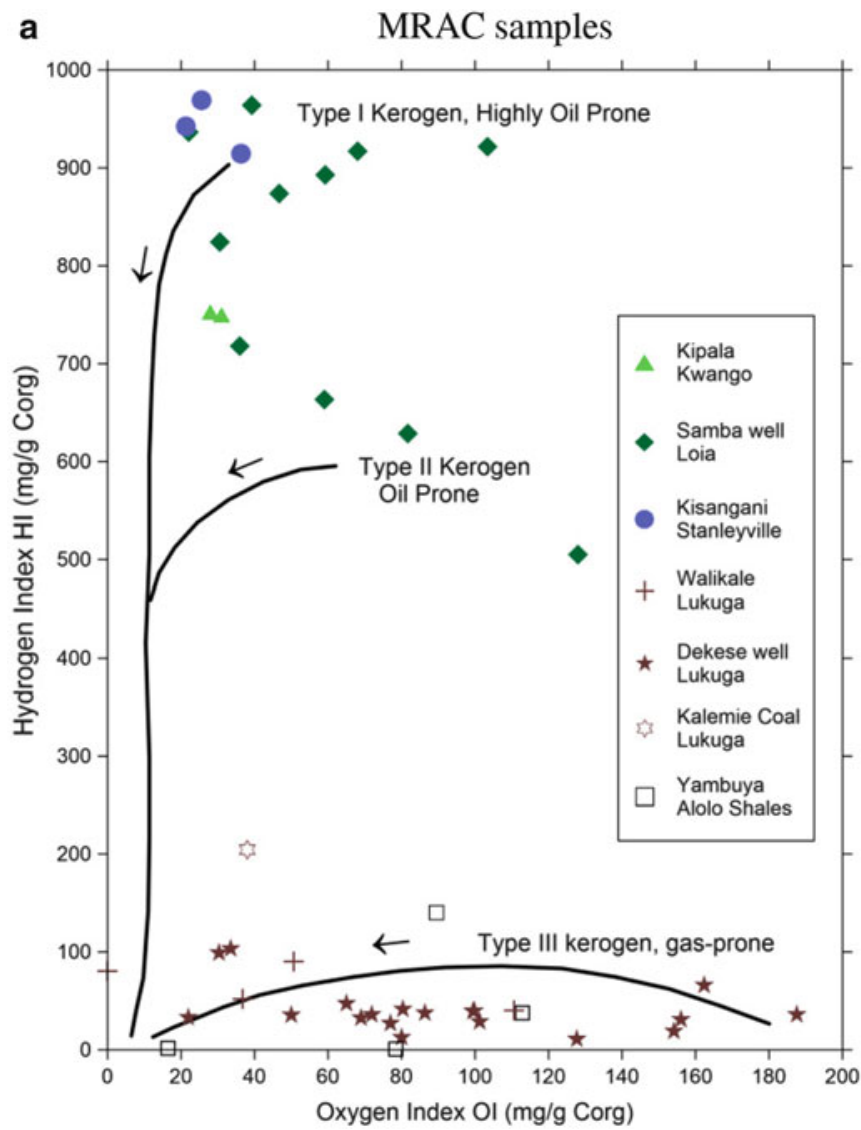

Fig. 18.4 Rock-Eval characterization of kerogen maturation characterized on a Espitalie diagram (Espitalie et al. 1977), by the Hydrogen Index HI and Tmax (temperature of maximum release of hydrocarbons). Bold lines show the evolution path of kerogen types with thermal maturation (along the direction shown by the arrows).

\subsection{Thermal Maturation}

The thermal evolution of the source rocks is evaluated by the Rock-Eval Tmax $\left({ }^{\circ} \mathrm{C}\right)$ parameter and vitrinite reflectance data $(\mathrm{Vr} \%)$. Using the Total Organic Carbon $\left(\mathrm{C}_{\text {org }}\right)$ content and Rock-Eval pyrolysis data, kerogen maturity level is expressed in the Van-Krevelen HI-OI (Fig. 18.3) and Espitalie HI-Tmax (Fig. 18.4) diagrams by composition trends in function of thermal maturation for different types of organic matter.

The Rock-Eval Tmax values correspond to temperature of maximal release of hydrocarbons during pyrolysis (summit of the S2 peak; Espitalie et al. 1977). On an Espitalie diagram, the Hydrogen Index (mg HC equivalent/g $\mathrm{C}_{\text {org }}$ ) decreases progressively with maturation, while the Tmax $\left({ }^{\circ} \mathrm{C}\right)$ increases (Fig. 18.4). In the Van-Krevelen diagram (Fig. 18.3), the vitrinite reflectance isolines separate the thermal maturation zones, with $\mathrm{Vr}=0.5 \%$ separating the Immature Zone from the Oil generation Zone and $\mathrm{Vr}=1.3 \%$ separating the Oil b

JNOC samples

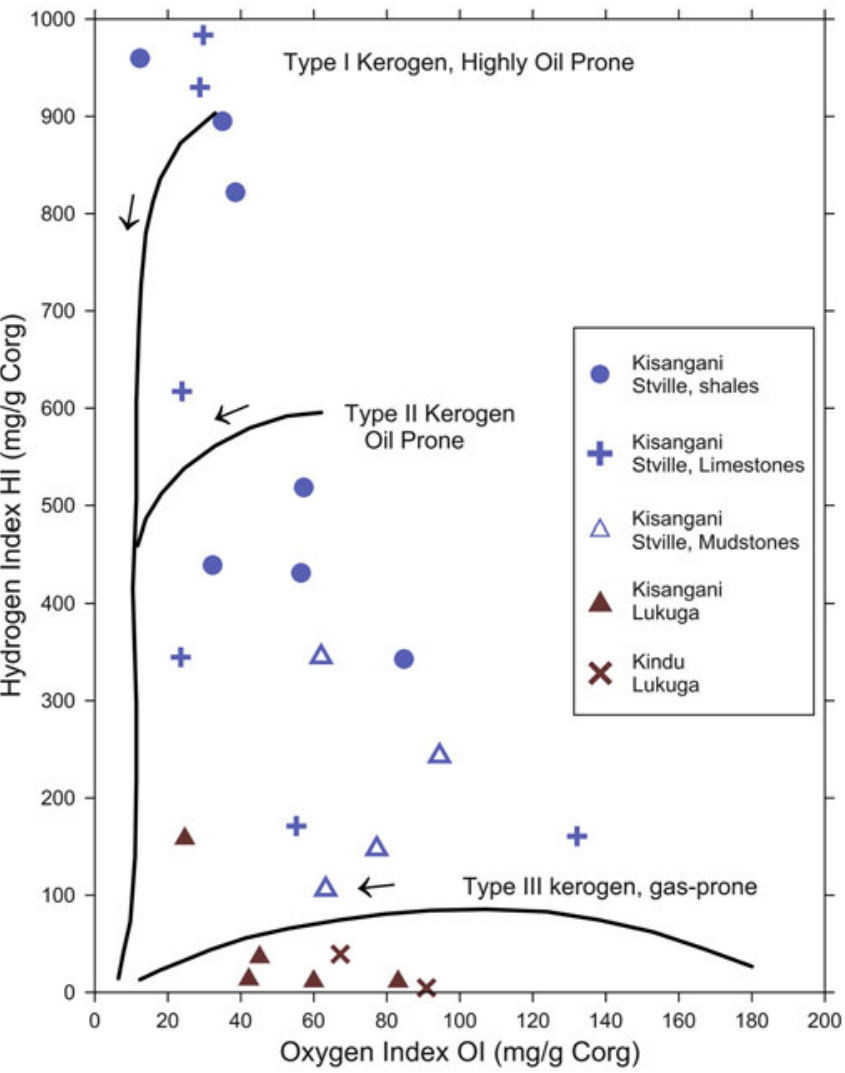

Dotted lines show maturation isogrades corresponding to vitrinite (or equivalent) values and separate the maturation zones. (a) RMCA samples, analyzed by RWTH Aachen (Sachse et al. 2012), with two samples of Kipala shales from Kadima (2007). (b) JNOC samples (JNOC 1984). Data from Tables 18.1 and 18.2

Zone from the Gas Zone. All the samples of the RMCA from the Stanleyville and Loia Groups and from the Kipala Shale fall in the Immature Zone. Some have Tmax values between 430 and $440^{\circ}$, but because they have high HI, they are still immature. Only a few samples of the Stanleyville Group collected by JNOC display HI lower than 450 and are close to the onset of the Oil Zone. The Stanleyville, Loia and Kipala source rocks are all immature, as indicated by their Tmax and $\mathrm{Vr}$ values.

Samples from the Lukuga Group present a range of Tmax values, between 410 and $455{ }^{\circ} \mathrm{C}$ (Fig. 18.3). The few outcrop samples analysed are in the same range, with a higher maturity for the varval shales of Walikale. Based on vitrinite reflectance (Table 18.2, Fig. 18.5), the gas-prone Lukuga source rocks are generally in the oil window in the Dekese well, except below 1,300 $\mathrm{m}$ deep, where they enter the gas window. However, the Tmax values indicate a lower maturity, mostly in the Immature Zone. On the Vr-Tmax diagram (Fig. 18.5), these values display an almost negative correlation, far from 


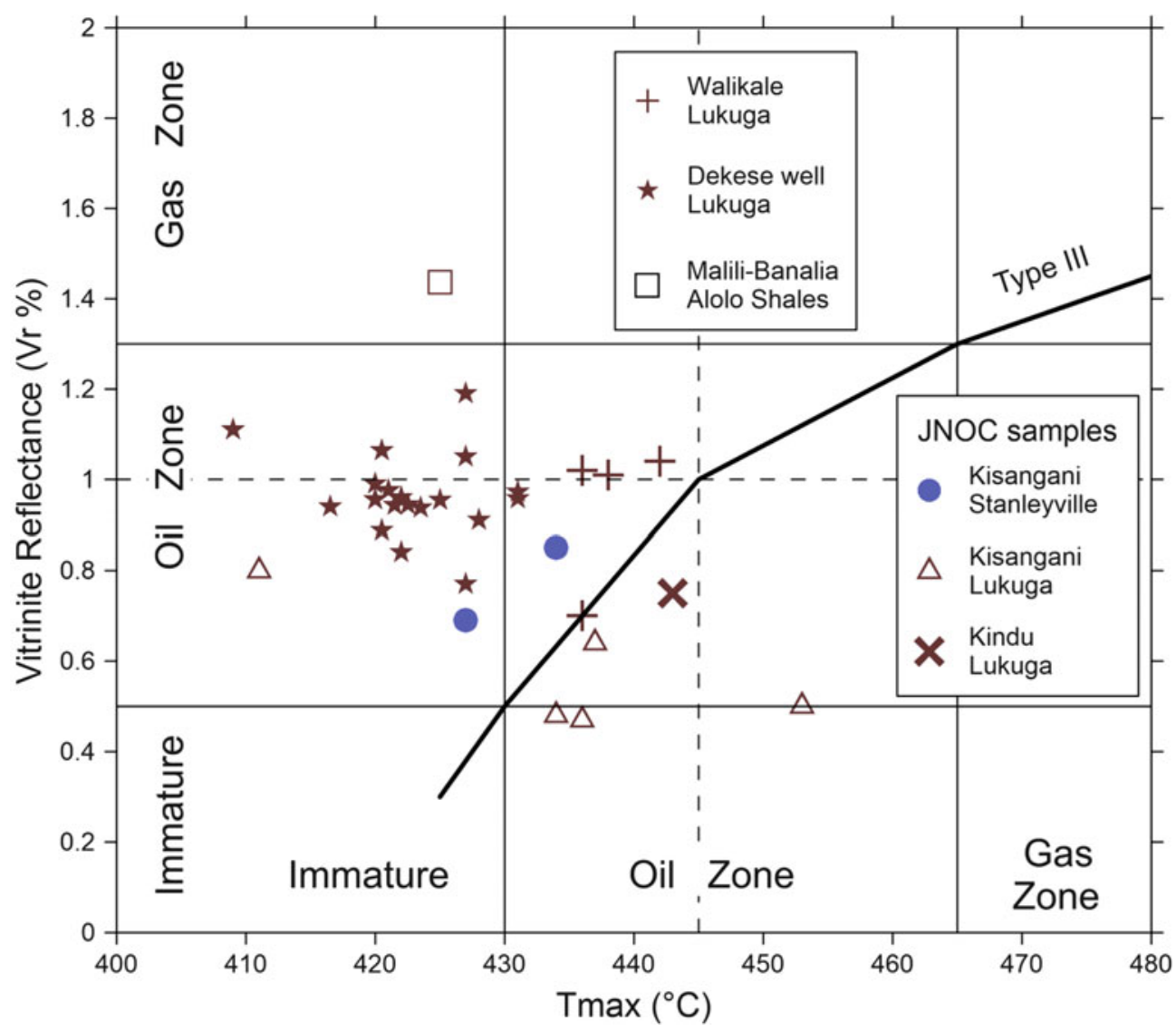

Fig. 18.5 Correlation between Tmax temperature and vitrinite reflectance values. Bold line shows the ideal evolution path for type III organic matter (Espitalie et al. 1977; Espitalie 1986). Most of the

the ideal evolution path constructed from literature data (Espitalie et al. 1977; Espitalie 1986). With reference to this evolution path, all the Dekese well samples display Vr values too high relative to corresponding Tmax. Such a shift is not seen for the other Lukuga samples (Walikale and Kisangani), or for the Stanleyville samples. This may be explained by contamination of the samples by recycled vitrinite, because petrological observations (Sachse et al. 2012) show that the samples from the Lukuga Group contain large amount of allochtonous vitrinite and vitrinite-like particles, mainly in the Dekese well.

The presence of allochtonous vitrinite in the Lukuga Group samples of the Dekese suggests that they have been recycled, possibly eroded from Lower Carboniferous to Upper Devonian rocks that may have been buried up to 3,000-4,000 m deep. Such rocks are not known in the CB, but do occur farther South, in South Africa and Namibia (e.g. Tankard et al. 2009).

All dark shales and limestones from the Neoproterozoic (Lenda carbonates of the Ituri Group, Mamungi shales of the Lokoma Group, Bangu black limestone of the Schisto-Calcaire Group) and the Lower to Middle Paleozoic sequences (Alolo
Lukuga Group samples from the Dekese well appear anomalous, with Vr value stoo high relative to Tmax. Data from Tables 18.1 and 18.2

Shales of the Aruwimi Group) are barren or contain residual organic matter; their maturity cannot be measured therefore with the Rock-Eval Tmax. The Tmax values for those few Alolo shales that are rich enough for a Rock-Eval analysis (from the Yambuya section), are not significant because the small amount of hydrocarbons generated during pyrolysis represent residual organic matter. These samples are also too old (Precambrian) to contain vitrinite particles.

\subsection{Reported Oil Seeps and Resource Potential for Petroleum}

Over the last 10 years several oil seeps have been reported within the CB (Fig. 18.1), although none of them have been found by the exploration companies that studied the basin in the 1950s and the 1970-1980s. They were re-visited and sampled between 2007 and 2008 by HRT Petroleum for analysing their biomarkers by GC-MS (Gas-Chromatography-Mass spectrometry), GC-IRM and diamontoids (Mello 2008). HRT Petroleum concentrated their investigations near Ilanga-Kole and Tolo along the Lukenie 
Fig. 18.6 Field photographs of hydrocarbon seep sites, taken during the 2011 MRACCOMICO field campaign (location on Fig. 18.1). (a) Frontal view of the Tolo seep site. (b) Pit drilled in the Tolo site trough a layer of soil mixed with rubbish. (c) Ilanga-Kolo seep site in a ditch along an old road, near a bridge. (d) Ilanga-Kole site: Impregnated gravel layer at base of superficial and above a compact clay layer. (e) Typical shore of Lake Inongo/MaiNdombe with lateritic promontories and sandy bays. (f) Mpunzuiboko beach with bitumen pellets covering the sand in the upper part of the beach
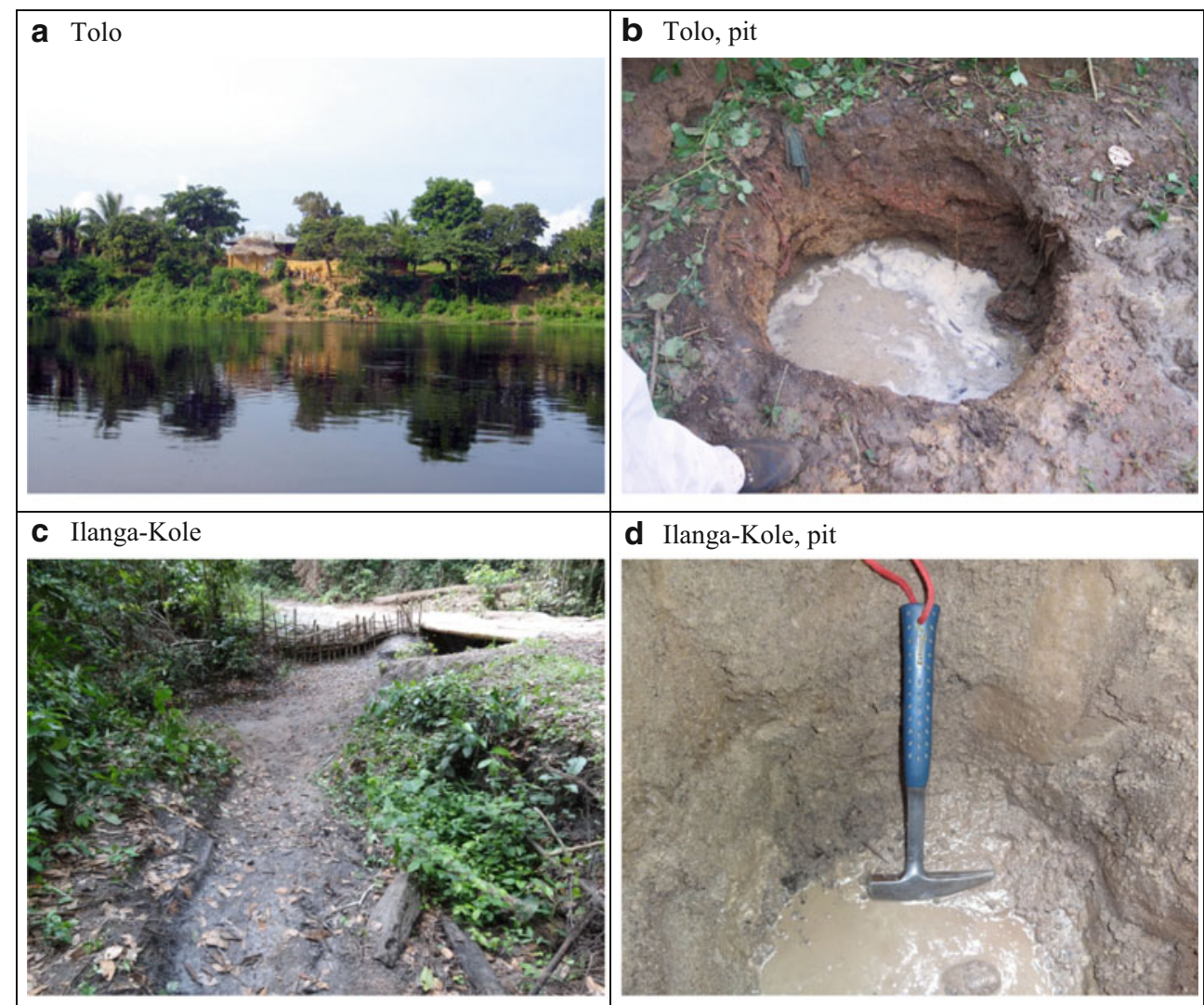

d Ilanga-Kole, pit

e Inongo lake shore
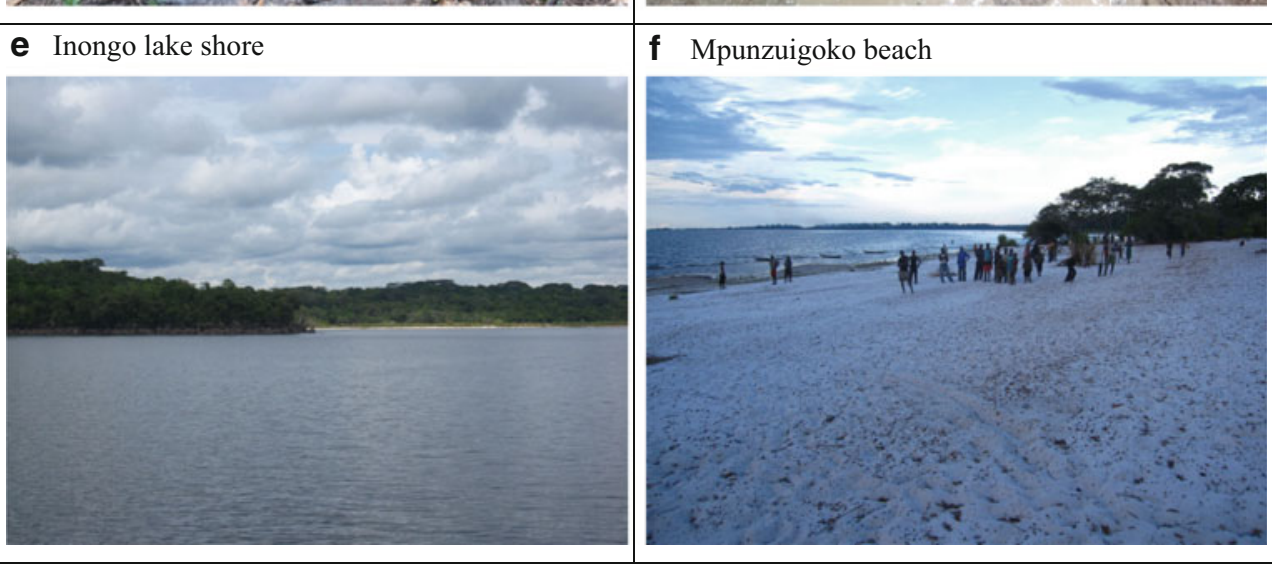

River and along the beaches of Lake Inongo (Mai-Ndombe). They reported that the biomarkers of the Ilanga-Kole and Tolo seeps suggest derivation of black oil from a marine source rock in the Late Cretaceous, mixed with an older, deeper marine source. The seeps contain a high concentration in Oleanane, a component present in the angiosperms, which appeared in Early Cretaceous and became dominant in the Late Cretaceous-Tertiary. Mello (2008) attribute them to some input from Neogene sediments, but source rocks are not known from the Neogene sequences. Mello (2008) thus predicted the presence of two or three active petroleum systems in the $\mathrm{CB}$, and speculated that it could hold 'giant to supergiant' (size not specified) accumulations of light oil, condensates and gas hydrocarbons, suggesting a promising petroleum province.
By contrast, Harriman (2011), disregarded the bitumens found on the beaches of Lake Inongo, and suggested they may be residues from the sealing of local fishing boats, and therefore likely of anthropic origin.

In 2011, we re-visited and re-sampled the Tolo and Ilanga-Kole seeps along the Lukenie River and the bitumen from the Mpunzuiboko beach along Lake Inongo (Figs. 18.1 and 18.6). The Tolo seep site was found along the river bank at the foot of $\mathrm{a} \sim 15 \mathrm{~m}$ high scarp that separates it from an inhabited plateau occupied by traditional houses. Beige-color clay with a slight odour of light hydrocarbons was found in a 1-m deep pit dug through a superficial layer of soil mixed with rubbish. At Ilanga-Kole, also along the Lukenie River and upstream Tolo, light hydrocarbons were 
found in a gravel layer on top of clay in a ditch along the old Oshwe-Bandundu road. On the shore of Lake Inongo, we sampled lumps of solid bitumen on the surface of white beach sands. We also sampled a fragment of the bitumen that was used to waterproof our wooden boat.

The collected samples were analysed by GHGeochem laboratories (Harriman 2012), and their anthropogenic origin confirmed for all of them. In summary, none of the hydrocarbon seeps appear to be natural oil seeps. They contain biomarkers that relate them to source rock which are too young, too mature and of marine affinity, for which no source rock are known in the $\mathrm{CB}$.

\section{Conclusions}

Based on the evidence presented, we do not share the optimism of HRT Petroleum for large potential oil reserves in the CB (e.g. Mello 2008). Todate no petroleum systems have yet been proven. The samples from the Mamungi shales have negligible organic matter content $\left(\mathrm{C}_{\text {org. }} \approx 0.1 \%\right.$ on average $)$, which do not allow any further organic geochemistry or thermal maturation analysis. Similarly, most of the Alolo shales analyzed also have negligible organic matter content, except a few samples from the Yambuya section, but which, when analyzed with the Rock Eval, appear to have no oil potential. Further, the Mamungi and Alolo shales are only known in outcrop and have not been formally recognized in the 4 wells drilled in the center of theCB.

The Lukuga Group that contains up to $2.4 \% \mathrm{C}_{\text {org }}$, is largely a gas-prone peri-glacial or interglacial lacustrine sequence of shales. Lacustrine sediments could have been deposited in more temperate conditions, but OM would be dominated by higher plants. The Stanleyville (Middle or Upper Jurassic) and Loia Groups (Middle Cretaceous) contain the best potential source rocks with some very rich shales (up to $25 \% \mathrm{C}_{\text {org }}$ ). The kerogen is derived from lacustrine algae, and is oil-prone type I (HI up to $950 \mathrm{mg}$ $\mathrm{HC}$ equivalent/g $\mathrm{C}_{\text {org }}$ ), but is too immature to have generated significant quantities of oil where they have been found. This Mesozoic petroleum system is, at the present state of knowledge, the best potential target for oil exploration.

In conclusion, there presently are no indications for any active hydrocarbon systems, but as the current knowledge of this large basin is still very limited, there is much room for future exploration. There is a clear need for more, new and modern geophysical and geological work to improve the basic knowledge of this vast region. This should be the backbone for future hydrocarbon exploration surveys. There is currently not enough knowledge on the geological evolution and architecture of the $\mathrm{CB}$ to predict the presence of viable hydrocarbon deposits.
Acknowledgements This work benefitted from many informal contacts and discussions that the first author had with individuals interested on the CB. We thank also the editorial efforts of M. de Wit and F. Guillocheau who motivated us to submit this paper.

\section{References}

Alvarez P, Maurin J-C, Vicat J-P (1995) La Formation de l'Inkisi (Supergroupe Ouest-congolien) en Afrique centrale (Congo et BasZaïre): un delta d'âge Paléozoïque comblant un bassin en extension. J Afr Earth Sci 20:119-131

Boze MM, Kar RK (1978) Biostratigraphy of the Lukuga Group in Zaïre.Ann. Mus. roy. Afr. cent., Tervuren (Belgique), Série in- $8^{\circ}$, Sciences géologiques, 82, 97-114

Buiter SJH, Stenberger B, Medvedev S, Tereault JL (2012) Could the mantle have caused subsidence of the Congo Basin? Tectonophysics 514-517:62-80

Cahen L (1954) Géologie du Congo belge. Vaillant-Caramanne, Liège, $577 \mathrm{pp}$

Cahen L (1983a) Le Groupe de Stanleyville (Jurassique supérieur et Wealdien de l'intérieur de la République du Zaïre): Révision des connaissances. Rapp. Ann. 1981-1982, Dép. Géol. Min. Mus. Roy. Afr. Cent., Tervuren (Belgique), 73-91

Cahen L (1983b) Brèves précisions sur l'âge des groupes crétaciques post-Wealdien (Loia, Bokungu, Kwango) du Bassin intérieur du Congo (République du Zaïre). Rapp. Ann., 1981-1982 Dép. Géol. Min. Mus. Roy. Afr. Cent., Tervuren (Belgique), 61-72

Cahen L, Ferrand JJ, Haarsma MJF, Lepersonne J, Verbeek, T. (1959) Description du Sondage de Samba. Ann. Mus. roy. Afr. cent., Tervuren (Belgique), Série in- $8^{\circ}$, Sciences géologiques, 29

Cahen L, Ferrand JJ, Haarsma MJF, Lepersonne J, Verbeek T (1960) Description du Sondage de Dekese. Ann. Mus. roy. Afr. cent., Tervuren (Belgique), Série in- $8^{\circ}$, Sciences géologiques, 34

Cahen L, Lepersonne J (1954) État actuel des connaissances relatives aux séries mésozoïques de l'intérieur du Congo. Bull Soc Belge Géol 77:20-37

Cahen L, Lepersonne J (1978) Synthèse des connaissances relatives au Groupe (anciennement Série) de la Lukuga (Permien du Zaire). Ann. Mus. roy. Congo belge, Tervuren (Belgique), série in-8, Sci. géol., 82, 115-152

Chorowicz J, Le Fournier J, MakazuMvumbi M (1990) La Cuvette Centrale du Zaïre : un bassin initié au Protérozoïque supérieur. Contribution de l'analyse du réseau hydrographique. C.R. Acad. Sci. Paris, t.311, Série II, 349-356

Colin JP (1981) Paleontological study of the Esso/Texaco well Gilson-1, Zaire. Unpublishedreport EPR-E.WA19.81

Colin JP (1994) Mesozoic-Cenozoic lacustrine sediments of the Zaïre Interior Basin. In: Gierlowski-Kordesch E, Kelts K (eds) Global geological record of lake basins. Cambridge University Press, Cambridge, pp 31-36

Cornet J (1911) Sur la possibilité de l'existence de gisements de pétrole au Congo. Ann Soc Geol Belg 36(1910-1911):9-15

Cox LH (1960) Further Mollusca from the Lualaba Beds of the Belgian Congo.Ann. Mus. Roy. Afr. Cent., Tervuren (Belgique), série in-8, Sci. géol., 37, $15 \mathrm{p}$

Crosby AG, Fishwick S, White N (2010) Structure and evolution of the intracratonic Congo Basin. Geochem Geophys Geosyst 11:Q06010

Daly MC, Lawrence SR, Diemu-Thiband K, Matouana B (1992) Tectonic evolution of the Cuvette centrale. Zaire J Geol Soc Lond 149: $539-546$ 
Delvaux D (2001) Tectonic and paleostress evolution of the Tanganyika-Rukwa-Malawi rift segment, East African Rift System. In: PA Ziegler, W Cavazza and AHF Robertson and S CrasquinSoleau, Eds. Peri-Tethys Memoir 6: PeriTethyan Rift/Wrench Basins and Passive Margins. Mém. Mus. Natn. Hist. nat., 186: 545-567. Paris

Delvaux D, Barth A (2010) African Stress Pattern from formal inversion of focal mechanism data. Implications for rifting dynamics. Tectonophysics 482:105-128

Delpomdor F, Linnemann U, Boven A, Gartner A, Travin A, Blanpied C, Hielsma H, Préat A (2013) Depositional age, provenance, tectonic and palaeoclimatic settings of the late Mesoproterozoic middle Neoproterozoic Mbuji-Mayi Supergroup, Democratic Republic of Congo. Palaeogeogr Palaeoclimatol Palaeoecol 389: $35-47$

de Sainte Seine P (1955) Poissons fossiles de l'étage de Stanleyville (Congo belge). $1^{\text {ère }}$ partie : la faune des argilites et schistes bitumineux. Ann. Mus. royal Afrique centrale, Tervuren (Belgique), série in-8, Sci. géol., 14, 125p

de Sainte Seine P, Casier E (1962) Poissons fossiles de l'étage de Stanleyville (Congo belge). $2^{\text {ème }}$ partie : la faune marine des calcaires de Songa. Ann. Mus. royal Afrique centrale, Tervuren (Belgique), série in-8, Sci. géol., 44, 52p

De Waele B, Johnon SP, Pisarevsky SA (2008) Paleoproterozoic to Neoproterozoic growth and evolution of the eastern Congo Craton: Its role in the Rodinia puzzle. Precambrian Res 160:127-141

Defrétin-Lefranc S (1967) Etude sur les Phyllopodes du Bassin du Congo. Ann. Mus. Roy. Afr. Cent., Tervuren (Belgique), série in8, Sci. géol., 56, $122 \mathrm{p}$

ECL (1988) Hydrocarbon potential of cuvette centrale (Republic of Zaire).Exploration Consultants Limited, Cellule Technique Pétrolière, Pétrozaire, unpublished report, 41 p. + figures, tables, appendices and enclosures

Egoroff A, Lombard AL (1962) Présence des couches de Stanleyville dans le sous-sol de Lépoldville, République du Congo (Note préliminaire). Ann Soc Geol Belg 85:103-109

Espitalie J (1986) Use of Tmax as a maturation index for different types of organic matter.Comparison with vitrinite reflectance. In: Burrus J (ed) Thermal modelling in sedimentary basins. Technip, Paris, pp 475-496

Espitalie J, Laporte JL, Madec M, Marquis F, Leplat P, Paulet J, Boutefeu A (1977) Méthode rapide de caractérisation des roches mères, de leur potentiel pétrolier et de leur degré d'évolution. Revue de l'Institut Français du Pétrole 32:23-42

ESSO Zaire SARL (1981a) Geological completion report.Mbandaka-1. Unpublished report

ESSO Zaire SARL (1981b) Geological completion report.Gilson-1. Unpublished report

Evrard P (1960) Sismique. (Résultat scientifique des missions du Syndicat pour l'étude géologique et minière de Cuvette congolaise). Ann. Mus. royal Afrique centrale, Tervuren (Belgique), série in-8, Sci. géol., 33, 87p

Fourmarier P (1914) Le bassin charbonnier d'agePermo-Triassique de la Lukuga. Etude géologique de la région de la Lukuga et de la Lubumba au voisinage du lac Tanganyika. Ann. Soc. géol. Belg., Publ. rel. Congo belge, Liege, 41, C77-227

Halbich W, Fitch FJ, Miller JA (1983) Dating the Cape orogeny, vol 12. Geological society of South Africa, Pretoria, pp 149-164, Special Publication

Harriman G (2011) Geochemical review of the Cuvette Centrale. The hydrocarbon potential of the Cuvette Centrale, DRC. A review of existing geochemical data on source rocks and seeps.GH Geochem Ltd, report GHG 2457, unpublished, 34p

Harriman G (2012) A Geochemical evaluation of outcrop and seep samples from the cuvette centrale, DRC.GH Geochem Ltd, unpublished draft report, $28 \mathrm{p}$
Henry J (1922-1923) Etude géologique du Congo belge dans la region comprise entre Basoko-Stanleyville, à l'Ouest, le lac Albert et la Semliki à l'Est. Ann Soc Geol Belg (Pub Rel Congo belge) 46: C49-313

Giresse P (2005) Mesozoic-Cenozoic history of the Congo Basin. J Afr Earth Sci 43:301-315

Grecoff N (1957) Ostracodes du bassin du Congo. -1 Jurassic supérieur et Crétacé inférieur du Nord du bassin. Ann. Mus. Roy. Afr. Cent., Tervuren (Belgique), série in-8, Sci. géol., 19, 97 p

Jamotte A (1931) Contribution à l'étude géologique du basin charbonnier de la Lukuga. Comité Spécial du Katanga: Annales du Service des Mines, 2, 3-44

JNOC (1984) Rapport des investigations géophysiques et géologiques dans la Cuvette centrale de la République du Zaïre. Japan National Oil Corporation, Unpublished, 205p

Kadima EK (2007) Stratigraphie, structure géologique et prospectivité pétrolière du Bassin de la Cuvette congolaise.DEA dissertation, Department of Geology, University of Lubumbashi, RDC, 126p

Kadima E, Delvaux D, Sebagenzi SN, Tack L, Kabeya M (2011a) Structure and geological history of the Congo Basin: an integrated interpretation of gravity, magnetic and reflection seismic data. Basin Res 23(5):499-527

Kadima EK, Sebagenzi S, Lucazeau F (2011b) A Proterozoic-rift origin for the structure and the evolution of the cratonic Congo Basin. Earth Planet Sci Lett 304:240-250

Kampunzu AB, Cailteux JLH (1999) Tectonic Evolution of the Lufilian Arc (Central Africa Copper Belt) During Neoproterozoic Pan African Orogenesis. Gondwana Res 2(3):401-421

Lawrence S, Makazu MM (1988) Zaire's Central basin.Prospectivity outlook. Oil Gas J 86(38):105-108

Le Roux JP (1995) Heartbeat of a mountain: diagnosing the age of depositional events in the Karoo (Gondwana) basin from the pulse of the Cape Orogen. Geol Rundschau 84:626-635

Lepersonne J (1974) Carte géologique du Zaïre au 1/2.000.000 et notice explicative, République du Zaïre, Direction de la Géologie, Kinshasa $\&$ Mus. Roy. Afr. Centr, Tervuren

Lepersonne J (1977) Structure géologique du bassin intérieur du Zaïre. Bull. Acad. Roy. Belg., Cl. Sci., $5^{\mathrm{e}}$ série, 63(12), 941-965, Bruxelles

Linol B (2013) Sedimentology and sequence stratigraphy of the Congo and Kalahari basins of South-Central Africa and their evolution during the formation and breakup of West-Gondwana. Ph.D. thesis Nelson Mandela Metropolitan University, South Africa, 370p

Lombard AL (1960) L'extension méridionale des couches de Stanleyville, Congo belge (Note préliminaire). Bull. Soc. Géol. Belg., 69, 23-27

Maheshwari H, Bose MN, Kumaran KP (1977) Mesozoic sporae dispersae from Zaire. II: The Loia and Bokungu Groups in the Samba borehole. III: Some miospores from the Stanleyville Group. Ann. Mus. roy. Afr. cent., Tervuren (Belgique), Série in- $8^{\circ}$, Sciences géologiques, 80

Mello MR (2008) Field survey, seep collection and HRGT analysis of seeps over CoMiCo exploration areas and samples correlation with Brazil, Africa and Middle-East. High Resolution Technology \& Petroleum (HRT), unpublished report, 130p

Misser F (2013) Enjeux et défis d'une province pétrolière en devenir. In : Madrysse S, Omasonbo J (eds) Conjonctures congolaises 2012. Politique, secteur minier et gestion des ressources naturelles en RD Congo. Cahiers Africains 82, 147-177. Musée royal de l'Afrique Centrale et Harmattan, Paris. ISBN 978-2-343-00465-5

Newton AR, Shone RW, Booth PW (2006) The Cape Fold Belt. In: Johnson MR, Anhaeusser CR, Thomas RJ (eds) The geology of South Africa. Geol. Soc. S. Africa. Johannesburg and Council for Geoscience, Pretoria, pp 521-530

Oils Search/Pioneer (2007) Cuvette centrale exploration study oils search limited/pioneer international development. Progress report. $65 \mathrm{p}$ 
Passau G (1923) La géologie du bassin des schistes bitumineux de Stanleyville (Congo belge). Ann. Soc. géol. Belg., Publ.rel. Congo belge 19 (1921-1922), C91-243

Pilipili Mawezi J (2010) Le pétrole de la République démocratique du Congo. Southern Africa Resource Watch, Johannesburg, South Africa, p 133

RRI (1988) Robertson Research International Ltd, Report 623/Ic.A Geochemical Investigation of the Cuvette Centrale of Zaire

Sachse VF, Delvaux D, Littke R (2012) Petrological and geochemical investigations of potential source rocks of the Central Congo Basin, DRC. AAPG Bull 96(2):277-300

Scotese CR (2009) Late Proterozoic plate tectonics and palaeogeography: a tale of two supercontinents, Rodinia and Pannotia, Special Publications, vol 326. Geological Society, London, pp 67-83

Sluys M (1945) La géologie de l'Ituri. Le Groupe de la Lindi Bull Serv Géol 1:95-182

Sluys M (1952) La géologie des environs de Stanleyville. Bull Inst Roy Col Belge 23(3):870-879

Tait J, Delpomdor F, Preat A, Tack L, Straathof G, Nkula VK (2011) Neoproterozoic sequences of the West Congo and Lindi/Ubangi Supergroups in the Congo Craton, Central Africa. In: Arnaud E, Halverson GP, Shields-Zhou G (eds) The geological record of Neoproterozoic Glaciations, vol 36. Geological Society of London, Memoirs, pp 185-194
Tankard A, Welsink H, Aukes P, Newton P, Settler E (2009) Tectonic evolution of the Cape and Karoo basins of South Africa. Mar Petrol Geol 26:1379-1412

Taverne L (1975a) A propos de trois Téléostéens Salmoniformes du Crétacé inférieur (Wealdien) du Zaïre, précédemment décrits dans les genres Leptolepis et Culpavus (PiscesTeleostei). Rev Zool Afr 89:481-504

Taverne L (1975b) Etude ostéologique de Leptolepiscaheni, Téléostéen fossile du Jurassique supérieur (Kimméridgien) de Kisangani (esStanleyville, Zaïre) précédemment décrit dans le genre Paraclupavus. Rev Zool Afr 89:821-853

Tissot BP, Welte DH (1978) Petroleum formation and occurrence. Springer, Berlin, p 538

Torsvik TH, Cocks LR (2011) The Palaeozoicpalaeogeography of central Gondwana. In: Van Hinsbergen DJJ, Buiter SJH, Torsvik $\mathrm{TH}$, Gaina C, Webb SJ (eds) The formation and evolution of Africa: a synopsis of $3.8 \mathrm{Ga}$ of Earth history. Geological Society, London, pp 137-166, Special Publications

Veatch AC (1935) Evolution of the Congo Basin. MemGeol Soc Am 3: 184

Verbeek T (1970) Géologie et lithologie du Lindien (Précambrien Supérieur du nord de la République Démocratique du Congo). Ann. Mus. Roy. Afr. Cent., Tervuren (Belgique), série in-8, Sci. géol., 66, $311 \mathrm{p}$ 